\title{
KOBİ'lerde Fonksiyonel Sorunların Performansa Etkisi: Tokat İli Örneği
}

\section{Doç. Dr. Yücel Erol ${ }^{1 *}$ \\ Mevlüde Başaran ${ }^{2}$}

Gelis tarihi: 31.03 .2020

Kabul tarihi: 09.05.2020

\section{Atıf bilgisi:}

IBAD Sosyal Bilimler Dergisi

Sayı: $7 \quad$ Sayfa: $403-428$

Yll: 2020 Dönem: Yaz

This article was checked by iThenticate. Similarity Index 15\%

Bu makalede araștırma ve yayın etiğine uyulmuştur.

${ }^{1}$ Tokat Gaziosmanpaşa Üniversitesi, Türkiye, yucel.erol@gop.edu.tr, ORCID ID 0000-0002-8289-9106

2Tokat Gaziosmanpaşa Üniversitesi, Türkiye, mevlude.basaran@kosgeb.gov.tr, ORCID ID 0000-0002-9029-9281

\section{* Sorumlu yazar}

ÖZ

Dünyada olduğu gibi ülkemiz açısından da ekonomik ve sosyal yapının gelişmesi için KOBİ'ler çok önemli bir yere sahiptir. Ancak KOBI'ler işletme fonksiyonları açısından pek çok sorunla karşılaşmaktadırlar. Bu çalışmanın amacı, KOBİlerin karşılaştıkları fonksiyonel sorunları analiz ederek işletme performansına etkisini ölçmektir. Araștırma kapsamını KOSGEB Tokat İl Müdürlüğü veri tabanına kayıtlı imalat işletmeler oluşturmaktadır. Verilerin analizinden ulaşılan bulgulara göre işletme fonksiyonu kapsamında yönetim, pazarlama, üretim, finans alanları ile ilgili sorunlar yaşadıkları belirlenmiştir. Bu sorunların KOBİ'lerin performansını etkilediğine ilişkin istatiksel olarak anlamlı sonuçlara ulaşılmıştır.

Anahtar Kelimeler: KOBİler, Fonksiyonel Sorunlar, Performans 


\title{
The Effect of Functional Problems on Performance in SMEs: Example of Tokat Province
}

\author{
Assoc. Prof. Dr. Yücel Erol ${ }^{1 *}$ \\ Mevlüde Başaran ${ }^{2}$
}

First received: 31.03 .2020

Accepted: 09.05.2020

\section{Citation:}

IBAD Journal of Social Sciences

Issue: 7

Pages: 403-428

Year: 2020

Session: Summer

This article was checked by iThenticate. Similarity Index 15\%

${ }^{1}$ Tokat Gaziosmanpaşa University, Turkey, yucel.erol@gop.edu.tr,

\section{ABSTRACT}

SMEs have a very important place for the development of the economic and social structure for our country as in the world. However, SMEs face many problems in terms of business functions. The purpose of this study is to analyze the functional problems faced by SMEs and measure their impact on business performance. The scope of the research is the manufacturing enterprises registered in the KOSGEB Tokat Provincial Directorate database. According to the findings obtained from the analysis of the data, it was determined that they had problems related to management, marketing, production, finance fields within the scope of business function. Statistically significant results have been reached regarding the fact that these problems affect the performance of SMEs.

Keywords: SMEs, Functional Issues, Performance

2Tokat Gaziosmanpaşa University, Turkey, mevlude.basaran@kosgeb.gov.tr, ORCID ID 0000-0002-9029-9281

* Corresponding Author 


\section{GİRIŞ}

Günümüzde ülke ekonomileri için hayati bir öneme sahip olan KOBİler, büyük işletmelerin çekirdeğini oluşturarak ekonomilere dinamizm kazandıran ve ülke ekonomilerinin ölçütü olan işletmelerdir. Bununla birlikte büyük işletmelerin ihtiyaç duydukları işlenmiş ya da yarı işlenmiş girdileri imal ederek, onların tamamlayıcısı pozisyonuna gelmektedirler. Böylece büyük işletmelerle işbirliği ve işbölümü içerisinde ekonomide yardımcı sanayi oluşturmaktadırlar. Tüm bunlar KOBİ'leri, ekonomilerin sürükleyicileri ve vazgeçilmezleri haline getirmektedir (Aypek, 2001, s. 145). Ekonomik büyüme noktasında başta $\mathrm{AB}$, Amerika Birleşik Devletleri (ABD) ve Japonya için Kobi'ler önemli bir öğe olarak kabul edilmektedir. KOBİ'lere verilen önemin nedenlerine bakıldığında ekonomilerin güçlü olabilmesi için büyük işletmelerin yanında ülkelerin belkemiğini oluşturan KOBİ'lere de ihtiyaç duyulması ve büyük işletmeler için bir tamamlayıcı görevi görmeleri gelmektedir. Ülkemizin sosyo-ekonomik ilerlemesi bakımından çok büyük paya sahip olan KOBİ'ler, dünya ekonomisinin olduğu gibi, Türkiye ekonomisinin de dinamik ve ilgi çeken öğelerindendir. KOBİ'ler emek yoğun ve düşük seviyede yönetim giderleri ile çalışan, az sermaye kullanan, çabuk karar veren ve ucuz üretim gerçekleştiren ekonomik birimler olarak tanımlanabilir (Akgemci, 2001, s. 7). KOBİ'lerin bu yönleri dinamik, yenilikçi ve firsatları zamanında değerlendirebilen işletmeler olmalarını sağlamaktadır. Ekonomik ve sosyal yapıda oldukça önemli bir yere sahip olmasına karşın küçük ve orta büyüklükte işletmeler, Türk ekonomisinin gündemine 1980'li yılların ortalarında girebilmiştir. Dünya Bankası ve uluslararası kalkınma örgütlerinin bu konudaki çalışmaları, sanayileşmiş ülke örnekleri ile Kobi'leri temsil eden meslek kuruluşlarının bu tür işletmelerin sistemin sağlıklı işleyiş̧ine katkısını artıracağını kavramış olmaları konuyu gündeme taşımıştır (Alpugan, 1998, s. 28-29). Ancak KOBİ'ler gereken ilgi ve önemi 1996 yılının KOBİ Yılı ilan edilmesi ile görmeye başlamışlardır. İşletmelerin kendine özgü yapılarından dolayı çözülmesi gereken sorunları bulunmaktadır. Çözülmesi gereken sorunlar için yapılacak her bir iyileştirme küçük sanayi işletmelerinin ülkemiz gelişmesine olan katkısını artıracaktır (Öztürk, 2007, s. 35). KOBİ’ler yönetim, pazarlama, üretim, finans, insan kaynakları, muhasebe gibi işletme fonksiyonları açısından birçok sorunla karşılaşmaktadırlar. Karşılaşılan bu sorunlar, KOBI'lerin amaçlarının gerçekleştirilmesi, büyümesi ve sürekliliğinin sağlanması açısından önemlidir. Bu sorunların tespit edilerek, çözüm önerilerinin getirilmesi gerekmektedir. Çünkü bu engelleri aşamayan işletmelerin başarılı olması günümüz yoğun rekabet ortamında zor görünmektedir. Bu çalışmada, Tokat ili imalat sanayinde faaliyet gösteren ve KOSGEB veri havuzunda yer alan 10 ve daha fazla çalışanı olan KOBİ'lerin işletme fonksiyonları açısından karşılaştıkları sorunların belirlemesi ve bu sorunların işletmelerin performansına etkisini ölçmek amaçlanmıştır. Bu amaçla ankete dayalı bir uygulamadan elde edilen veriler analiz edilerek değerlendirilmiş ve yorumlanmıştır.

\section{Kavramsal Çerçeve ve Literatür Özeti}

Dünyanın birçok ülkesinde olduğu gibi ülkemizde de genel kabul görmüş ortak bir Kobi tanımına rastlanmamaktadır. Yine küçük işletmeleri belirlemek amacıyla kullanılan standart bir ölçüt bulunmamaktadır. Yapılan tanımlar ülkelerin sanayileşme düzeyine, pazar büyüklüğüne, işletmelerin faaliyet alanlarına ve kullanılan üretim tekniklerine bağlı olarak farklılık göstermekte, ayrıca aynı ülke içerisinde de bir bölgeden diğerine veya sektörler arasında farkl1lıklar gösterebilmektedir. Ülkelerin kalkınma düzeyleri ve sektörler arasındaki farklılık ortak bir tanımlamaya engel olmaktadır (Tunca ve Yüce, 2007, s. 46). Kobi'leri ifade etmek için kullanılan tanımlar ve ölçütler konusunda bilim adamları ve araştırmacılar arasında da görüş birliği bulunmamaktadır. Ülkeler arası çeşitli farklılıklar ortak tanım yapılmasına engel olurken, tanım yapılırken kullanılan ölçütlerin farklılığı ise pek çok tanımın kabul görmesini sağlamaktadır. Çünkü ülkelerin işletmeleri sınıflandırma anlayışlarının farklı olması ve zamana göre değişebilmesi, tanım için kullanılan kriterlerin farklı olması ayrı tanımların kabul görmesini sağlamaktadır (Taş, 2010, s. 30). Kobi tanımının yapılmasında çeşitli nicel ve nitel ölçütler kullanılmaktadır. Yapılan kimi tanımlar, bu nicel ve nitel ölçütlerin tamamına yakınını kapsarken kimi tanımlar ise birkaç tane ölçütü içermektedir. Nicel ölçütler, işletme ile ilgili, rakamlarla ifade edilebilen değerleri temel almaktadır. İşletmelerin küçük, orta ve büyük işletmeler şeklinde sınıflandırılmalarında birçok ülkede daha fazla dikkate alınması, nicel ölçütleri önemli hale getirmektedir. KOBİ'lerin nicel ölçütler yardımıyla tanımlanması, birçok problemle boğuşan bu tür işletmelerin devlet teşvikleri ve çeşitli kuruluşların sağladığı desteklerden ne ölçüde 
yararlanacaklarının tespitinde objektiflik sağlamaktadır (Çelik ve Kalaycı, 2007, s. 6). Kullanılan nicel ölçütler aynı ülkede, aynı anda, örgütsel yapılarca amaçlarına göre değişiklik gösterebilirken, zamanla değişikliğe uğrayabilmektedirler. $\mathrm{Bu}$ nedenle nicel ölçütler küçük işletme tanımının yapılmasını olanaksız hale getirir. $\mathrm{Bu}$ sıkıntıların giderilebilmesi için Kobi’lerin tanımlanmasında sadece nicel ölçütler değil bunun yanı sıra sayısal olarak ifade edilmeyen nitel ölçütlerde kullanılmaktadır(Kulakoğlu, 2013, s.13). Bu çalışmada, 19/10/2005 tarihli Bakanlar Kurulu kararıyla çıkarılan, 18/11/2005 tarihli ve 25997 sayılı Resmi Gazete'de yayımlanan 2005/9617 Karar sayıl1, Küçük ve Orta Büyüklükteki İşletmelerin Tanımı, Nitelikleri ve Sınıflandırılması Hakkında Yönetmelik'e göre; Küçük ve orta büyüklükte işletme (KOBİ): İki yüz elli kişiden az yıllık çalışan istihdam eden ve yıllık net satış hasılatı veya mali bilançosundan herhangi biri yüz yirmi beş milyon Türk Lirasını aşmayan ve bu Yönetmelikte mikro işletme, küçük işletme ve orta büyüklükteki işletme olarak sınıflandırılan ekonomik birimleri veya girişimleri ifade eder (30/4/2018 tarihli ve 2018/11828 sayılı Bakanlar Kurulu Kararı Eki Yönetmeliğin 1 inci maddesiyle değiştirilen güncel tanım) kullanılmıştır (www.resmigazete.gov.tr/2005/11/20051118.htm).

Konuyla ilgili akademik anlamda uygulamalı çalışmalar incelendiğinde; Akgemci (2001), Mali olanakların yetersiz olduğunu, profesyonel yönetim anlayışına gereken önemin verilmediğini, KOBi mevzuatı ve uygulamaların bürokratik engel olarak görüldüğünü belirlemiştir. Asal (2001), KOBİ'lerin örgütlenme ve yönetim sorunu, üretimde meydana gelen sorunlar, üretimin de etkisinde olan hammadde ve tedarik sorunları ve tüm bu sorunların temel nedeni olan finansman sorunu yaşadıklarını belirlemiştir. Özgener(2003), Büyüme sürecindeki KOBI'lerin yönetim ve organizasyon sorunları belirlemek amacıyla Nevşehir Un Sanayii işletmeleri üzerine yaptığı araştırmada KOBİ'lerin büyüme sürecindeki yönetim ve organizasyon sorunları analiz edilmiştir. Araştırma sonucunda işletmelerin yönetim tarzı, personel tedariki ve eğitimi, organizasyon yapıları, planlama becerileri, yetki devri, karar verme, kurumsallaşma, kalite anlayışı ve büyüme konusundaki eğilimlere ilişkin bulgular elde edilmiştir. Torlak ve Uçkun(2005), Eskişehir'deki KOBI'lerin pazarlama ve finansman sorunları üzerine yaptıkları araştırma sonuçlarına göre, işletmelerin en ciddi finansman sorunlarının nakit para sıkıntısı, piyasa durgunluğu ve kredi faizlerinin yüksekliği olduğu, pazarlama sorunları bakımından ise işletmelerin yeni ürün geliştirme güçlügü, tüketici tercihlerinin hızlı değişimi ve rakiplerin fiyat anlaşmaları sorunlarıyla ağırlıklı olarak karşı karşıya oldukları tespit etmişlerdir. Özkanlı ve Namazalieva(2006), Kırgızistan'daki KOBI'lerin karşılaştıkları yönetim sorunlarını belirleyerek çözüm önerileri geliştirmek amacıyla yaptıları saha araştırmasında,Kobi'lerin büyük kısmında profesyonel yönetici istihdam edilmediği, planlamanın uzmanlar tarafından yapılmadığı, örgütlemenin basit ve biçimsel olmadığı, bilinçli personel seçimi olmadığından kalifiye personel istihdamında zorlukların bulunduğu, mevcut personel eğitimine önem verilmediği, yönetimin yöneltme fonksiyonunun kısmen gerçekleştirildiği, denetimin sahip yöneticiler tarafından yapıldığı saptanmışlardır. Çelik ve Karadal (2007), "Pazarlama stratejilerinin geliştirilmesi" ve "ürün ve hizmetlerin fiyatlandırılması" sorunlarının "genel olarak işletmenin performans düzeyi" üzerinde etkili olduğunu tespit etmişlerdir. Akbulut (2007), Finansal sorunların KOBİ'lerin öncelikli sorunu olduğunu belirlemiştir. Serinkan ve Cabar(2008), KOBI'lerin yönetim ve organizasyon sorunları üzerine Denizli'deki tekstil işletmeleri üzerine yaptıkları çalışmada, planlama, uyumlaştırma, denetim, yetki devri, karar alma, organizasyona, kurumsallaşma, insan kaynakları ve eğitime ilişkin sorunlara yönelik bulgular elde etmişlerdir. Kahraman (2012), KOBİ'lerin çoğunluğunun finansal sorun yaşadığını, bu finansal sorunlarını bankalar aracılığı ile aşmaya çalıştıklarını ve çözüm için finansman araçları hakkında yeterli bilgi sahibi olmadıkları sonucuna ulaşmıştır.

$\mathrm{Bu}$ çalışmada, işletme fonksiyonları olan yönetim, pazarlama, üretim ve finans kapsamında karşılaşılan sorunlara yer verilmiş ve aşağıdaki hipotezler oluşturulmuştur:

$\mathrm{H}_{1}$ :Kobi'lerin organizasyon fonksiyonu açısından karşılaştıkları sorunlar işletmenin genel performansinı etkiler.'

$\mathrm{H}_{2}$ : Kobi'lerin yöneltme fonksiyonu açısından karşılaştıkları sorunlar işletmenin genel performansını etkiler. 
$\mathrm{H}_{3}$ :Kobi'lerin koordinasyon fonksiyonu açısından karşılaştıkları sorunlar işletmenin genel performansinı etkiler.

$\mathrm{H}_{4}$ : Kobi'lerin denetim(kontrol) fonksiyonu açısından karşılaştıkları sorunlar işletmenin genel performansinı etkiler.

$\mathrm{H}_{5:}$ Kobi'lerin pazarlama fonksiyonu açısından karşılaştıkları sorunlar işletmenin genel performansını etkiler.

$\mathrm{H}_{6}$ :Kobi'lerin üretim fonksiyonu açısından karşılaştıkları sorunlar işletmenin genel performansını etkiler.

$\mathrm{H}_{7 \text { : }}$ Kobi'lerin finans fonksiyonu açısından karşılaştıkları sorunlar işletmenin genel performansını etkiler.

\section{Kobilerin İşletme Fonksiyonları Açısından Karşılaştıkları Sorunların Performansa Etkisi Üzerine Bir Araştırma}

Çalıșma KOBİ'lerin işletme fonksiyonları açısından karşılaştıkları sorunların işletmelerin performansına etkisini ölçmek amacıyla yapılan ankete dayalı uygulamadan oluşmaktadır. $\mathrm{Bu}$ bölümde araştırmanın amacı ve önemi, yöntemi ve kapsamı, verilerin toplanması, değerlendirilmesi, hipotezleri ve araştırmadan elde edilen bulgular yer almaktadır.

\subsection{Araştırmanın Amacı ve Önemi}

Araştırmanın temel amacı, imalat sanayinde faaliyet gösteren KOBİ'lerin işletme fonksiyonları açısından karşılaştı̆̆ı sorunların işletmelerin performansına etkisini ölçmektir. Bu konuda yapılan çalışmaların ülkemizde sınırlı olduğu da dikkate alındığında çalışmanın ilgili literatüre katkısının olacağ düşünülmektedir.

\subsection{Araştırmanın Kapsamı ve Yöntemi}

Bu araştırmanın ana kütlesini KOSGEB Tokat il Müdürlüğü veri tabanına kayıtlı 10 ve daha fazla çalışanı olan ve imalat sanayinde faaliyet gösteren 95 küçük ve orta büyüklükte işletme oluşturmaktadır. 2019 yılı Şubat ayı başı itibariyle toplam 95 işletmenin 2015, 2016 ve 2017 yıllarına ait KOSGEB KOBİ Bilgi Beyannamelerinin onaylı olduğu belirlenmiştir. KOSGEB desteklerinden yararlanabilmek için bir işletmenin güncel KOBİ Bilgi Beyannamesinin onaylı olması gerekmektedir. 2015, 2016 ve 2017 yıllarının seçilmesinin nedeni bu yıllara ait beyannameleri onaylı olan işletmelerin veri tabanında aktif olmalarından dolayıdır. Örneklem alınmamış tam sayım yapılmış olup 95 işletmenin tamamına anket gönderilmiştir. Toplam 67 işletmeden( $\% 70$ oranında) geri dönüş sağlanmıştır. Bu araştırmada kullanılan yaklaşımı betimleyici bir yaklaşımdır. Betimleyici yaklaşım verilen bir durumu aydınlatmak, değerlendirmeler yapmak ve olaylar arasında olası ilişkileri ortaya çıkarmak için yürütülür. Bu tür araştırmalarda asıl amaç incelenen durumu etraflıca tanımlamak ve açıklamaktır. Bu araştırmalarda incelenen olayın özellikleri, şartları bozulmadan, inceleme yapılan ortamda herhangi bir değişiklik yapmadan araştırmalar yürütüldüğü için araştırmacılar tarafindan genelde tercih edilmektedir. Betimsel analizde farklı kişilerin aynı soru hakkında farklı düşüncelerinin görüşülenlerden elde edildiği tarzda aktarılır (Altunışık vd.2010, s.322). Bu yaklaşımda hipotezlerin test edilmesi amaçlanmaktadır.

\section{Bulgular ve Değerlendirme}

\subsection{Demografik Özellikler}

Araştırma kapsamı içerisinde yer alan işletmelerde sahip/yöneticilerin yaşlarına, cinsiyetlerine, öğrenim seviyelerine, pozisyonlarına, işletmedeki çalışma sürelerine ilişkin bulgulara ulaşılmıştır. $\mathrm{Bu}$ bulgularda yaş dağılımına göre; katılımcıların ; \% 25,4'ü 21-30, \% 46,3’ü 31-40, \% 26,9’u 41-50 ve $\%$ 1,5'i 51 ve üzeri yaş aralığında olduğu belirlenmiştir. Cinsiyetlerine göre, katılımcıların \% 77,6's1 erkek, \% 22,4 kadındır. Öğrenim seviyesine göre; lise ve dengi düzeyde eğitim alanlar \% 19,4 oranında, ön lisans düzeyinde eğitim alanlar \% 26,9 oranında, lisans düzeylerinde eğitim alanlar \% 43,3 ve lisansüstü düzeyde eğitim alanlar ise \% 10,4 oranında dağılmaktadır. İşletmedeki 
pozisyonlarına göre; işletme sahibi/ortağı olanlar \% 37,3, yönetici sınıfinda olanlar (müdür/müdür yardımcıs1, genel koordinatör, mühendis, muhasebe sorumlusu ve satış pazarlama sorumlusu) $\% 62,7$ oranında dağılmaktadır. İşletmedeki çalışma sürelerine göre; $1-5$ yıl arası \% 37,3, 6-10 yıl arası \% 41,9 ve $11-15$ yıl arası \% 10,4 ve 15 yıl üzeri olanlar \%10,4 oranında dağılmaktadır.

İşletmelerin çalışan sayılarına, sektördeki faaliyet sürelerine, hukuki yapılarına ve sektörüne ilişkin bulgulara ulaşılmıştır. Ayrıca işletmelerin aile işletmesi olup olmadıkları, kaçıncı nesil tarafindan yürütüldükleri, üst düzeyde çalışan aile üyesi sayısı bilgileri elde edilmiştir. İşletme bünyesinde çalışan sayısına göre; 10-49 kişi arasında çalışana sahip olanlar \% 79,1, 50-149 kişi arasında çalışana sahip olanlar \% 17,9, 150-249 kişi arasında çalışana sahip olanlar \% 3 oranında dağılmaktadır. İşletmenin sektördeki faaliyet süresine (firma yaşı) göre; 5 yıldan az süredir faaliyet gösterenler \% 6 , 6-10 y1l arasında faaliyet gösterenler \% 10,4, 11-15 y1l arasında faaliyet gösterenler \% 26,9 ve 16 y1l üzerinde faaliyet gösterenler \% 56,7 oranında dağılmaktadır. Hukuki yapısına göre; şahıs işletmesi olanlar \% 4,5 limited şirket olanlar \% 80,6, anonim şirket olanlar \% 14,9 oranında dağılmaktadır. Aile işletmesi olup olmamasına göre; aile işletmesi olanlar \% 53,7, aile işletmesi olmayanlar \% 46,3 oranında dağılmaktadır. İşletmenin kaçıncı nesil tarafından yönetildiğine göre; 1 . nesil olanlar \% 47,2, 2. nesil olanlar $\% 30,6,1$. ve 2 . nesil beraber olanlar $\% 13,9,3$. nesil olanlar $\% 8,3$ oranında, dağılmaktadır. Üst düzeyde çalışan aile üyesi sayısına göre; 1 olanlar \% 14,7, 2 olanlar \% 55,9, 3 olanlar \% 8,8, 4 olanlar \% 11,8, 5 olanlar \% 2,9 ve 6 olanlar \% 5,9 oranında dağılmaktadır. İşletmenin hangi alanda faaliyette bulunduğuna göre; gıda-içki ve tütün alanında faaliyette bulunanlar \% 20,9, orman ürünleri ve mobilya alanında faaliyette bulunanlar \% 11,9, dokuma-giyim eşyası ve deri alanında faaliyette bulunanlar $\% 23,9$, metal alanında faaliyette bulunanlar $\% 6$, taş ve toprağa dayalı alanda faaliyette bulunanlar \% 20,9, kimya-petrol-kömür-kauçuk ve plastik alanında faaliyette bulunanlar \% 8,9, metal eşya-makine, teçhizat ulaşım araçları, ilmi ve mesleki ölçme aletleri alanında faaliyette bulunanlar \% 7,5 oranında, dağılmaktadır.

\subsection{Güvenilirlik Analizi}

Çalışmada kullanılan ölçeğin güvenilirlik düzeyinin belirlenmesi için güvenilirlik analizi yapılmış ve Cronbach Alfa katsayısı elde edilmiştir. Çalışmada kullanılan likert ölçekli soruların geneli için Cronbach Alfa katsayısı 0,869 olarak elde edilmiştir.

\section{3. İşletme Fonksiyonu İle İlgili Bulgular}

\subsubsection{Yönetim Fonksiyonu}

Planlama fonksiyonu ile ilgili olarak işletmelere birden çok seçenekli olan sorulara verilen cevaplara göre; planlama yapanlar \% 95,5 oranında, planlama yapmayanlar \% 4,5 oranında dağılmaktadır. Planlamanın kim tarafından yapıldığı bilgisine göre; işletme sahibi tarafından yapılanlar \% 35,9 oranında, üst yönetim tarafından yapılanlar \% 46,9 oranında, planlama departmanı tarafindan yapılanlar \% 14,1 oranında ve diğer ( üretim müdürü, mali müşavir) \% 3,1 oranında dağılmaktadır. İşletme faaliyetlerinde planlama yapılmama nedenlerine göre; "içinde bulunulan koşullar (ekonomik kriz, siyasal iktidarsızlık) planlama yapmayı olanaksız duruma getirmektedir" diyenler \% 66,7 oranında, "işletmede uzun dönemli planlama yapacak uzmanlar bulunmamaktadır" diyenler \% 33,3 oranında dağılmaktadır.

KOBI'lere uygulanan ankete bağlı olarak likert ölçeğinde sorulan sorulardan elde edilen bulgular değerlendirilmiştir. Değerlendirmelerde regresyon analizi ve ki-kare bağımsızlık testi kullanılmıştır. $\mathrm{Bu}$ değerlendirmeler 1şığında çalışmada oluşturulan hipotezlerin desteklenip desteklenmediği açıklanmıştır.

$\mathrm{H}_{1}$ :KOBİ'lerin organizasyon fonksiyonu açısından karşılaştıkları sorunlar işletmenin genel performansinı etkiler. 
Tablo 1. Organizasyon Ifadelerine Katılım Düzeyinin Performansa Etkisi

\begin{tabular}{|c|c|c|c|c|c|c|}
\hline & \multicolumn{2}{|c|}{$\begin{array}{l}\text { Standart } \\
\text { Olmayan } \\
\text { Katsayılar }\end{array}$} & \multirow{2}{*}{$\begin{array}{c}\text { Standart } \\
\text { Katsayılar } \\
\text { Beta }\end{array}$} & \multirow[b]{2}{*}{$\mathrm{t}$} & \multirow[b]{2}{*}{$\mathrm{p}$} \\
\hline & & B & $\begin{array}{l}\text { Std. } \\
\text { Hata }\end{array}$ & & & \\
\hline \multirow{6}{*}{$\begin{array}{l}\text { Genel Performans ve } \\
\text { Başar1 } \\
F=2,526 ; p=0,038 \\
R^{2}=0,172\end{array}$} & Sabit & 2,582 & 0,530 & & 4,875 & 0,000 \\
\hline & $\begin{array}{l}\text { İşletmede açık ve net olarak } \\
\text { hazırlanmış bir organizasyon } \\
\text { şeması mevcuttur }\end{array}$ & $-0,400$ & 0,254 & $-0,402$ & $-1,572$ & 0,121 \\
\hline & $\begin{array}{l}\text { İşletmede açık ve net bir } \\
\text { şekilde hazırlanmış iş } \\
\text { tanımları mevcuttur }\end{array}$ & 0,698 & 0,217 & 0,702 & 3,220 & 0,002 \\
\hline & $\begin{array}{l}\text { İşletmemizde alt kademedeki } \\
\text { yöneticiler üst düzey } \\
\text { yöneticilere görüş ve önerileri } \\
\text { ile destek olur. }\end{array}$ & 0,099 & 0,186 & 0,101 & 0,535 & 0,595 \\
\hline & $\begin{array}{l}\text { Aile üyesi olmayan } \\
\text { yöneticilerin yetki ve } \\
\text { sorumlulukları sınırlıdır }\end{array}$ & $-0,136$ & 0,097 & $-0,175$ & $-1,402$ & 0,166 \\
\hline & $\begin{array}{l}\text { Yönetim, profesyonel } \\
\text { yöneticilere devredilmiștir }\end{array}$ & $-0,122$ & 0,104 & $-0,183$ & $-1,177$ & 0,244 \\
\hline
\end{tabular}

Organizasyon ile ilgili ifadelerin bağımsız, işletme performans ve başarı düzeyinin ise bă̆ımlı değişken olarak alındığı regresyon modelinde, bağımsız değişkenlerin bağımlı değişken olan genel performans ve başarı üzerindeki etkisi ölçülmüştür. Regresyon modelinin anlamlılık düzeyi incelendiğinde, kurulan regresyon modelinin anlamlı olduğu görülmektedir $(F=2,526 ; p<0,05)$. Model içerisindeki parametrelerin anlamlılık düzeyi incelendiğinde; "işletmede açık ve net bir şekilde hazırlanmış iş tanımları mevcuttur" ifadesine katılım düzeyinin işletmenin genel performans ve başarısı üzerinde anlamlı düzeyde etkisinin olduğu görülmektedir.

$\mathrm{H}_{2}$ : KOBI'lerin yöneltme fonksiyonu açısından karşılaştıkları sorunlar işletmenin genel performansını etkiler.

Tablo 2. Yöneltme Ifadelerine Katıllm Düzeyinin Performansa Etkisi

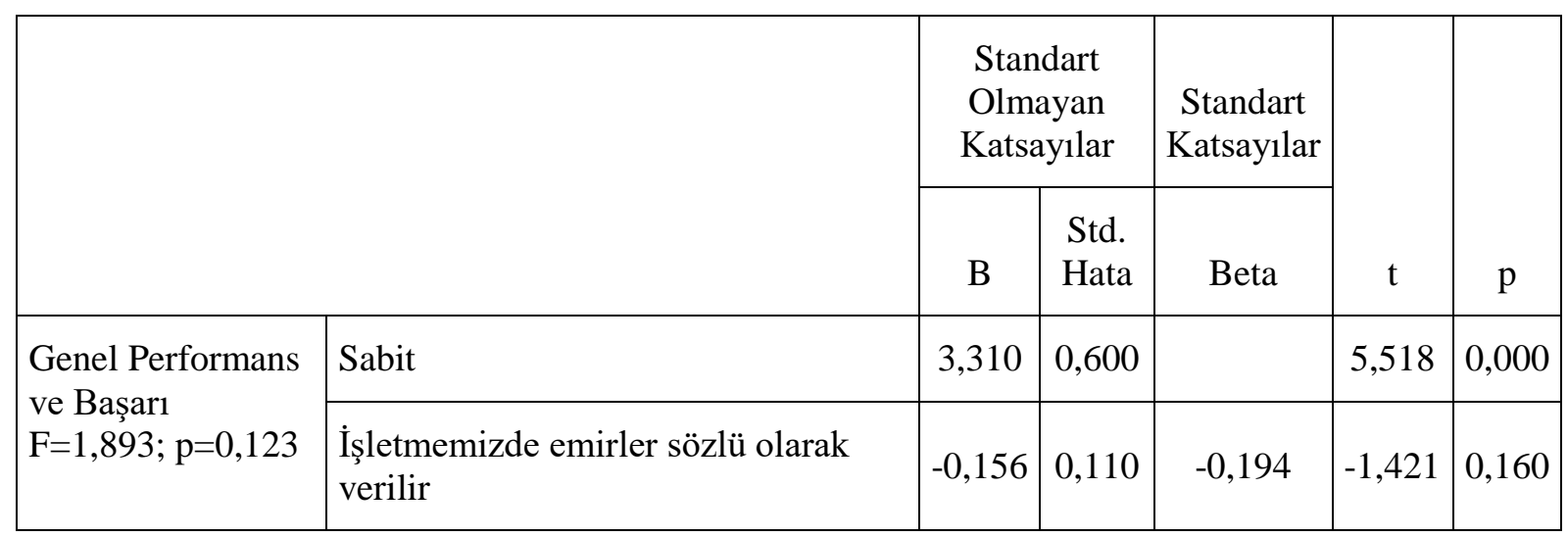




\begin{tabular}{|l|l|l|l|l|l|l|}
$\mathrm{R}^{2}=0,028$ & $\begin{array}{l}\text { İşletmemizde emirler yazılı olarak ve } \\
\text { yönergelere başvurularak verilir }\end{array}$ & $-0,082$ & 0,116 & $-0,096$ & $-0,708$ & 0,482 \\
\hline $\begin{array}{l}\text { Çalışanlar maddi ve/veya manevi } \\
\text { karşılık verilmeksizin her türlü emri } \\
\text { yerine getirmek zorundadırlar }\end{array}$ & $-0,096$ & 0,101 & $-0,122$ & $-0,950$ & 0,346 \\
\hline $\begin{array}{l}\text { Etkili ve verimli personele yaptıkları } \\
\text { katkı oranında maddi ve/veya manevi } \\
\text { karşı1ıklar vererek motivasyonlarını } \\
\text { sağlarım }\end{array}$ & 0,269 & 0,144 & 0,242 & 1,868 & 0,066 \\
\hline
\end{tabular}

Yöneltme ile ilgili ifadelerin bağımsız, işletme performans ve başarı düzeyinin ise bağımlı değişken olarak alındığı regresyon modelinde, bağımsız değişkenlerin bağımlı değişken olan genel performans ve başarı üzerindeki etkisi ölçülmüştür. Regresyon modelinin anlamlılık düzeyi incelendiğinde, kurulan regresyon modelinin anlamlı olmadığ görülmektedir $(\mathrm{F}=1,893 ; \mathrm{p}>0,05)$. Diğer bir ifade ile yöneltme ile ilgili ifadelere katılım düzeyinin işletme genel performans ve başarısı üzerinde istatistiksel olarak anlamlı bir etkisi bulunmadığ sonucuna ulaşılmıştır.

$\mathrm{H}_{3}$ :KOBİ'lerin koordinasyon fonksiyonu açısından karşılaştıkları sorunlar işletmenin genel performansinı etkiler.

Tablo 3. Koordinasyon Ifadelerine Katılım Düzeyinin Performansa Etkisi

\begin{tabular}{|c|c|c|c|c|c|c|}
\hline & \multicolumn{2}{|c|}{$\begin{array}{c}\text { Standart Olmayan } \\
\text { Katsayilar }\end{array}$} & \multirow{2}{*}{$\begin{array}{c}\text { Standart } \\
\text { Katsayilar } \\
\text { Beta }\end{array}$} & \multirow[b]{2}{*}{$\mathrm{t}$} & \multirow[b]{2}{*}{$\mathrm{p}$} \\
\hline & & B & $\begin{array}{l}\text { Std. } \\
\text { Hata }\end{array}$ & & & \\
\hline \multirow{3}{*}{$\begin{array}{l}\text { Genel } \\
\text { Performans } \\
\text { ve Başar1 } \\
F=2,197 ; \\
p=0,120 \\
R^{2}=0,064\end{array}$} & Sabit & 1,868 & 0,686 & & 2,722 & 0,008 \\
\hline & $\begin{array}{l}\text { İşletmenin geleceği ile ilgili } \\
\text { amaç, plan ve programları uyum } \\
\text { içerisindedir }\end{array}$ & $-0,079$ & 0,263 & $-0,065$ & $-0,302$ & 0,764 \\
\hline & $\begin{array}{l}\text { İ̧şletmenin farklı bölümlerinin } \\
\text { görevleri ve faaliyetleri arasında } \\
\text { birlik ve uyum sağlanmış, iş } \\
\text { bölümü yapılmıştır }\end{array}$ & 0,421 & 0,299 & 0,305 & 1,409 & 0,164 \\
\hline
\end{tabular}

Koordinasyon ile ilgili ifadelerin bağımsız, işletme performans ve başarı düzeyinin ise bağımlı değişken olarak alındığı regresyon modelinde, bağımsız değişkenlerin bağımlı değişken olan genel performans ve başarı üzerindeki etkisi ölçülmüştür. Regresyon modelinin anlamlılık düzeyi incelendiğinde, kurulan regresyon modelinin anlamlı olmadığ1 görülmektedir $(F=2,197 ; p>0,05)$. Diğer bir ifade ile koordinasyon ile ilgili ifadelere katılım düzeyinin işletme genel performans ve başarısı üzerinde istatistiksel olarak anlamlı bir etkisi bulunmadığı sonucuna ulaşılmıştır

$\mathrm{H}_{4}:$ KOBİ'lerin denetim(kontrol) fonksiyonu açısından karşılaştıkları sorunlar işletmenin genel performansinı etkiler. 
Tablo 4. Denetim (Kontrol) Ifadelerine Katılım Düzeyinin Performansa Etkisi

\begin{tabular}{|c|c|c|c|c|c|c|}
\hline & \multicolumn{2}{|c|}{$\begin{array}{c}\text { Standart olmayan } \\
\text { katsayılar }\end{array}$} & \multirow{2}{*}{$\begin{array}{c}\begin{array}{c}\text { Standart } \\
\text { katsayılar }\end{array} \\
\text { Beta }\end{array}$} & \multirow[b]{2}{*}{$\mathrm{t}$} & \multirow[b]{2}{*}{$\mathrm{p}$} \\
\hline & & B & $\begin{array}{l}\text { Std. } \\
\text { Hata }\end{array}$ & & & \\
\hline \multirow{3}{*}{$\begin{array}{l}\text { Genel Performans } \\
\text { ve Başar1 } \\
F=8,812 ; p=0,000 \\
R^{2}=0,216\end{array}$} & Sabit & 1,979 & 0,518 & & 3,819 & 0,000 \\
\hline & $\begin{array}{l}\text { Denetimde yazılı belgeler, } \\
\text { istatistiki veriler, raporlar ve } \\
\text { analizler dikkate alınır }\end{array}$ & 0,475 & 0,119 & 0,448 & 4,006 & 0,000 \\
\hline & $\begin{array}{l}\text { İşletme denetim sürecini } \\
\text { kendi düşünce ve } \\
\text { yorumlarıma göre } \\
\text { gerçekleştiririm }\end{array}$ & $-0,169$ & 0,092 & $-0,204$ & $-1,826$ & 0,073 \\
\hline
\end{tabular}

Denetim ile ilgili ifadelerin bağımsız, işletme performans ve başarı düzeyinin ise bağımlı değişken olarak alındığı regresyon modelinde, bağımsız değişkenlerin bağımlı değişken olan genel performans ve başarı üzerindeki etkisi ölçülmüsşür. Regresyon modelinin anlamlılık düzeyi incelendiğinde, kurulan regresyon modelinin anlamlı olduğu görülmektedir $(\mathrm{F}=8,812 ; \mathrm{p}<0,05)$. Model içerisinde bulunan parametrelerin anlamlılık düzeyi incelendiğinde; "Denetimde yazılı belgeler, istatistiki veriler, raporlar ve analizler dikkate alınır" ifadesine katılım düzeyi arttıkça, işletmenin genel başarı ve performans düzeyinin de anlamlı düzeyde arttığı görülmektedir. "İşletme denetim sürecini kendi düşünce ve yorumlarıma göre gerçekleştiririm" ifadesine katılım düzeyinin ise işletme genel performans ve başarısı üzerinde anlamlı bir etkisi bulunmamaktadır.

\subsubsection{Pazarlama Fonksiyonu}

$\mathrm{H}_{5}$ KOBİ'lerin pazarlama fonksiyonu açısından karşılaştıkları sorunlar işletmenin genel performansını etkiler.

Tablo 5. Pazarlama Ifadelerine Katılım Düzeyinin Performansa Etkisi

\begin{tabular}{|c|c|c|c|c|c|c|}
\hline & \multicolumn{2}{|c|}{$\begin{array}{c}\text { Standart } \\
\text { olmayan } \\
\text { katsayılar }\end{array}$} & \multirow{2}{*}{$\begin{array}{c}\begin{array}{c}\text { Standart } \\
\text { katsay1lar }\end{array} \\
\text { Beta }\end{array}$} & \multirow[b]{2}{*}{$\mathrm{t}$} & \multirow[b]{2}{*}{$\mathrm{p}$} \\
\hline & & B & $\begin{array}{l}\text { Std. } \\
\text { Hata }\end{array}$ & & & \\
\hline \multirow{5}{*}{$\begin{array}{l}\text { Genel } \\
\text { Performans ve } \\
\text { Başar1 } \\
F=1,145 ; \\
p=0,347 \\
R^{2}=0,170\end{array}$} & Sabit & 3,850 & 0,588 & & 6,548 & 0,000 \\
\hline & Pazar bulma güçlüğü çekmekteyiz & $-0,086$ & 0,122 & $-0,107$ & $-0,705$ & 0,484 \\
\hline & $\begin{array}{l}\text { Yoğun rekabet ortamından } \\
\text { etkilenmekteyiz }\end{array}$ & $-0,245$ & 0,208 & $-0,283$ & $-1,178$ & 0,244 \\
\hline & $\begin{array}{l}\text { Piyasadaki fiyat istikrarsızlığından } \\
\text { etkilenmekteyiz }\end{array}$ & 0,205 & 0,205 & 0,215 & 1,003 & 0,320 \\
\hline & $\begin{array}{l}\text { Kalite düşüklüğü ile oluşan } \\
\text { problemler yaşamaktayiz }\end{array}$ & $-0,149$ & 0,127 & $-0,198$ & $-1,170$ & 0,247 \\
\hline
\end{tabular}




\begin{tabular}{|l|c|c|c|c|c|}
$\begin{array}{l}\text { Yetersiz reklam ve promosyondan } \\
\text { etkilenmekteyiz }\end{array}$ & 0,069 & 0,139 & 0,088 & 0,496 & 0,622 \\
\hline $\begin{array}{l}\text { Dağıtım kanallarıyla ilgili } \\
\text { problemler yaşamaktayız }\end{array}$ & 0,093 & 0,159 & 0,116 & 0,584 & 0,561 \\
\hline $\begin{array}{l}\text { Satı̧ elemanlarının etkin } \\
\text { olmamasından dolayı problem } \\
\text { yaşamaktayız }\end{array}$ & $-0,157$ & 0,144 & $-0,214$ & $-1,094$ & 0,279 \\
\hline $\begin{array}{l}\text { Ambalajlama ve paketleme } \\
\text { sorunları yaşamaktayız }\end{array}$ & 0,182 & 0,143 & 0,243 & 1,269 & 0,210 \\
\hline $\begin{array}{l}\text { Markalaşma konusunda zorluk } \\
\text { çekiyoruz }\end{array}$ & $-0,091$ & 0,145 & $-0,128$ & $-0,627$ & 0,533 \\
\hline $\begin{array}{l}\text { Hammadde temininde zorluk } \\
\text { çekmekteyiz }\end{array}$ & $-0,012$ & 0,154 & $-0,015$ & $-0,079$ & 0,937 \\
\hline
\end{tabular}

Pazarlama ile ilgili ifadelerin bağımsız, işletme performans ve başarı düzeyinin ise bağımlı değişken olarak alındığı regresyon modelinde, bağımsız değişkenlerin bağımlı değişken olan genel performans ve başarı üzerindeki etkisi ölçülmüştür. Regresyon modelinin anlamlllık düzeyi incelendiğinde, kurulan regresyon modelinin anlamlı olmadığı görülmektedir $(F=1,145 ; p>0,05)$. Diğer bir ifade ile pazarlama ile ilgili ifadelere katılım düzeyinin işletme genel performans ve başarısı üzerinde istatistiksel olarak anlamlı bir etkisi bulunmadığ sonucuna ulaşılmıştır.

\subsection{3.Üretim Fonksiyonu}

$\mathrm{H}_{6}$ :KOBİ'lerin üretim fonksiyonu açısından karşılaştıkları sorunlar işletmenin genel performansını etkiler.

Tablo 6. Üretim Sorunları Yaşama Düzeyinin Performansa Etkisi

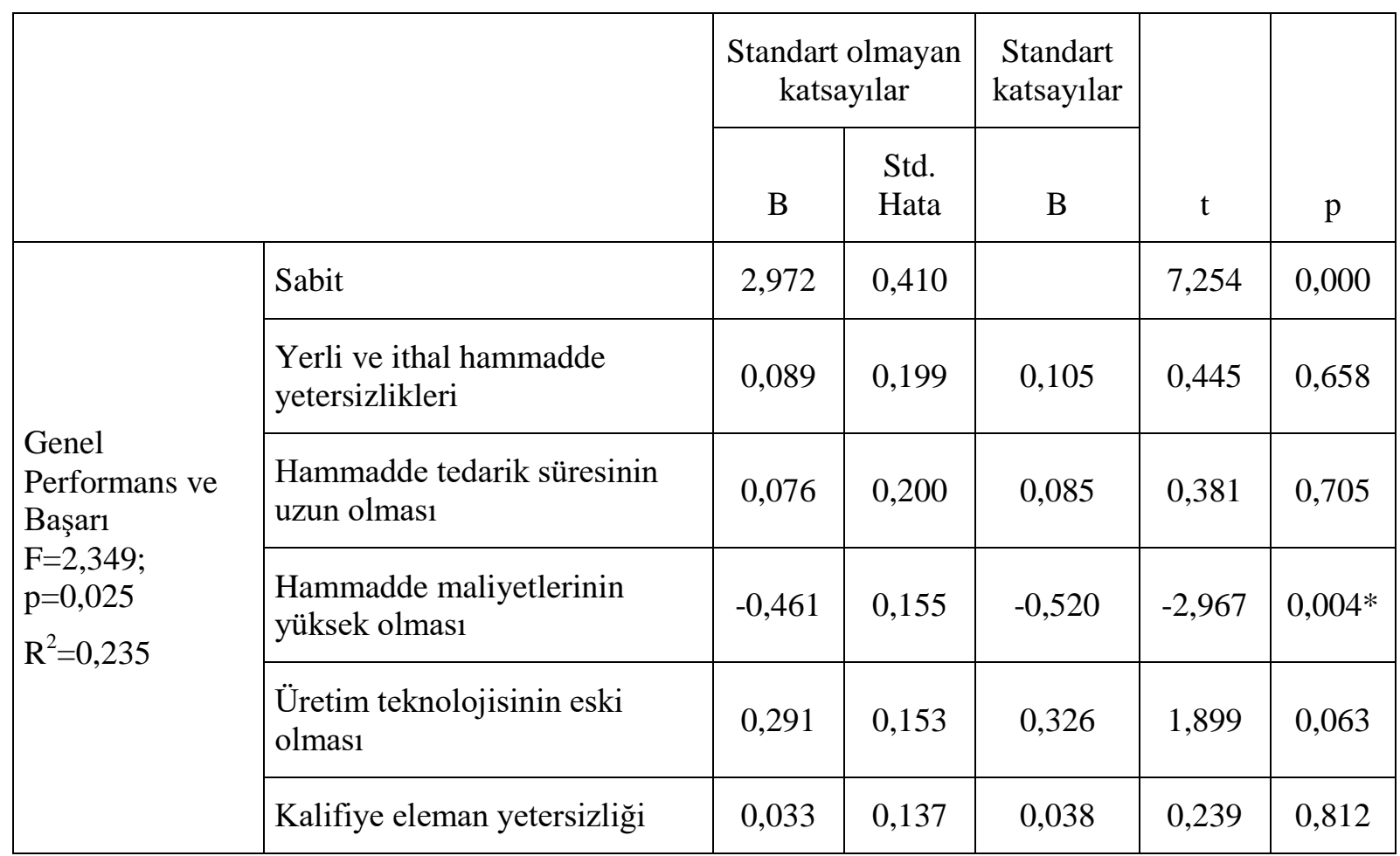




\begin{tabular}{|l|c|c|c|c|c|}
$\begin{array}{l}\text { Üründe istenen kalite } \\
\text { standardını karşılayamama }\end{array}$ & $-0,230$ & 0,182 & $-0,264$ & $-1,263$ & 0,212 \\
\hline Stoklardaki artı̧̧lar & 0,137 & 0,155 & 0,156 & 0,887 & 0,379 \\
\hline Teslimatta gecikmeler & $-0,308$ & 0,202 & $-0,357$ & $-1,525$ & 0,133 \\
\hline $\begin{array}{l}\text { Kapasite kullanımı ile ilgili } \\
\text { sorunlar }\end{array}$ & 0,426 & 0,171 & 0,503 & 2,484 & $0,016^{*}$ \\
\hline
\end{tabular}

Üretim ile ilgili sorun yaşama düzeyinin bağımsız, işletme performans ve başarı düzeyinin ise bağımlı değişken olarak alındığı regresyon modelinde, bağımsız değişkenlerin bağımlı değişken olan genel performans ve başarı üzerindeki etkisi ölçülmüştür. Regresyon modelinin anlamlılık düzeyi incelendiğinde, kurulan regresyon modelinin anlamlı olduğu görülmektedir $(\mathrm{F}=2,349 ; \mathrm{p}<0,05)$. Model içerisindeki parametrelerin anlamlılık düzeyi incelendiğinde; hammadde maliyetlerinin yüksek olması ve kapasite kullanım oranı ile ilgili sorun yaşama durumunun işletmenin genel performans ve başarısı üzerinde anlamlı düzeyde etkisinin olduğu görülmektedir.

\subsubsection{Finans Fonksiyonu}

$\mathrm{H}_{7}$ KOBİ'lerin finans fonksiyonu açısından karşılaştıkları sorunlar işletmenin genel performansını etkiler.

Tablo 7. Finansal Sorun Yaşama Düzeyinin Performansa Etkisi

\begin{tabular}{|c|c|c|c|c|c|c|}
\hline & \multicolumn{2}{|c|}{$\begin{array}{l}\text { Standart olmayan } \\
\text { katsayılar }\end{array}$} & \multirow{2}{*}{$\begin{array}{c}\begin{array}{c}\text { Standart } \\
\text { katsayilar }\end{array} \\
\text { Beta }\end{array}$} & \multirow[b]{2}{*}{$\mathrm{t}$} & \multirow[b]{2}{*}{$\mathrm{p}$} \\
\hline & & B & $\begin{array}{l}\text { Std. } \\
\text { Hata }\end{array}$ & & & \\
\hline \multirow{9}{*}{$\begin{array}{l}\text { Genel } \\
\text { performans } \\
\text { ve başarı } \\
F=1,402 ; \\
p=0,215 \\
R^{2}=0,146\end{array}$} & Sabit & 2,533 & 0,871 & & 2,907 & 0,005 \\
\hline & Kredi bulamamak & $-0,319$ & 0,162 & $-0,450$ & $-1,969$ & 0,054 \\
\hline & Kredi maliyetinin yüksekliği & 0,095 & 0,140 & 0,128 & 0,675 & 0,502 \\
\hline & $\begin{array}{l}\text { Alacakların zamanında tahsil } \\
\text { edilememesi }\end{array}$ & 0,300 & 0,196 & 0,244 & 1,527 & 0,132 \\
\hline & İ̇sletme sermayesi yetersizliği & 0,033 & 0,245 & 0,036 & 0,134 & 0,894 \\
\hline & Öz kaynakların yetersizliği & $-0,010$ & 0,200 & $-0,012$ & $-0,052$ & 0,959 \\
\hline & Maliyetlerin yüksekliği & $-0,059$ & 0,216 & $-0,047$ & $-0,273$ & 0,786 \\
\hline & $\begin{array}{l}\text { Teminata verilen çek ve senetlerin } \\
\text { vadesinden önce tahsili }\end{array}$ & $-0,031$ & 0,123 & $-0,044$ & $-0,251$ & 0,803 \\
\hline & Teşviklerin azaltılması & 0,110 & 0,138 & 0,120 & 0,799 & 0,428 \\
\hline
\end{tabular}

Finans ile ilgili sorun yaşama düzeyinin bağımsız, işletme performans ve başarı düzeyinin ise bağımlı değişken olarak alındığı regresyon modelinde, bağımsız değişkenlerin bağımlı değişken olan genel performans ve başarı üzerindeki etkisi ölçülmüştür. Regresyon modelinin anlamlılık düzeyi incelendiğinde, kurulan regresyon modelinin anlamlı olmadığ 1 görülmektedir $(F=2,526 ; p>0,05)$. 
Diğer bir ifade ile finans ile ilgili sorun yaşama düzeyinin işletme genel performans ve başarısı üzerinde istatistiksel olarak anlamlı bir etkisi bulunmadığ sonucuna ulaşılmıştır.

Yöneltme ile ilgili ifadelere katılım düzeyinin işletmedeki pozisyon ile ilişkisinin belirlenmesi için kikare analizi yapılmıştır.

$\mathrm{H}_{8}$ :Yöneltme sorunları ile ilgili alg1 düzeyi katılımcıların işletmedeki pozisyonuna göre anlamlı farklıl1k göstermektedir.

Tablo 8. Yöneltme İle İlgili Iffadelere Katılım Düzeyinin Işsletmedeki Pozisyon İle İlişkisi

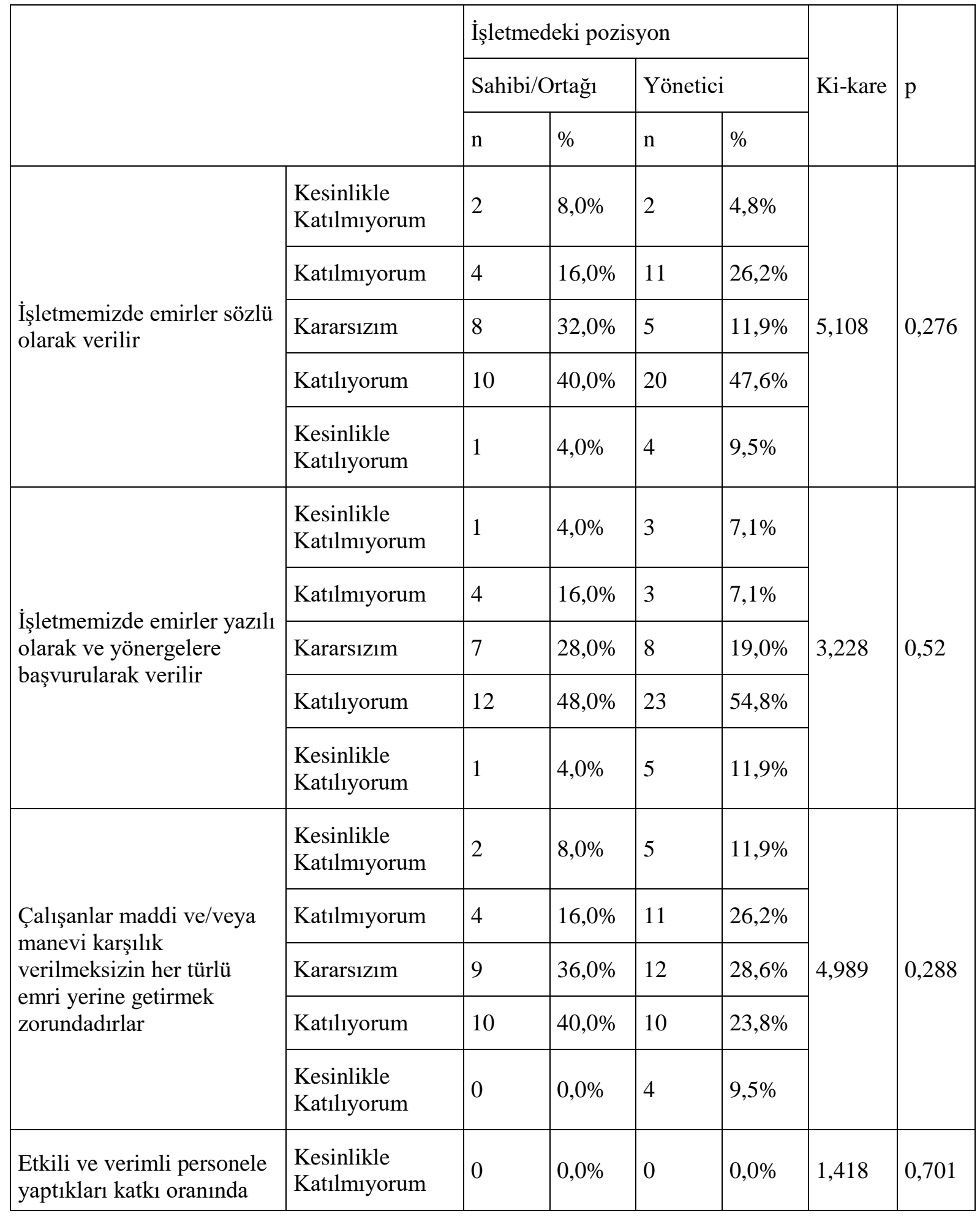


maddi ve/veya manevi karş1lıklar vererek motivasyonlarını sağlamak zorundadırlar

\begin{tabular}{|l|l|l|l|l|} 
Katılmiyorum & 1 & $4,0 \%$ & 3 & $7,1 \%$ \\
\hline Kararsızım & 5 & $20,0 \%$ & 8 & $19,0 \%$ \\
\hline Kat1lıyorum & 16 & $64,0 \%$ & 22 & $52,4 \%$ \\
\hline $\begin{array}{l}\text { Kesinlikle } \\
\text { Kat1lıyorum }\end{array}$ & 3 & $12,0 \%$ & 9 & $21,4 \%$ \\
\hline
\end{tabular}

Ki-kare analizi sonuçlarına göre yöneltme ile ilgili ifadelere katılım düzeyi ile işletmedeki pozisyon arasında anlamlı düzeyde ilişki bulunmamaktadır ( $\mathrm{p}>0,05)$.

Koordinasyon ile ilgili ifadelere katılım düzeyinin işletmedeki pozisyon ile ilişkisinin belirlenmesi için ki-kare analizi yapılmıştır.

$\mathrm{H}_{9}$ :Koordinasyon sorunları ile ilgili algı düzeyi katılımcıların işletmedeki pozisyonuna göre anlamlı farkl111k göstermektedir.

Tablo 9. Koordinasyon İle İlgili Iffadelere Katılım Düzeyinin Isşletmedeki Pozisyon İle İlişsisi

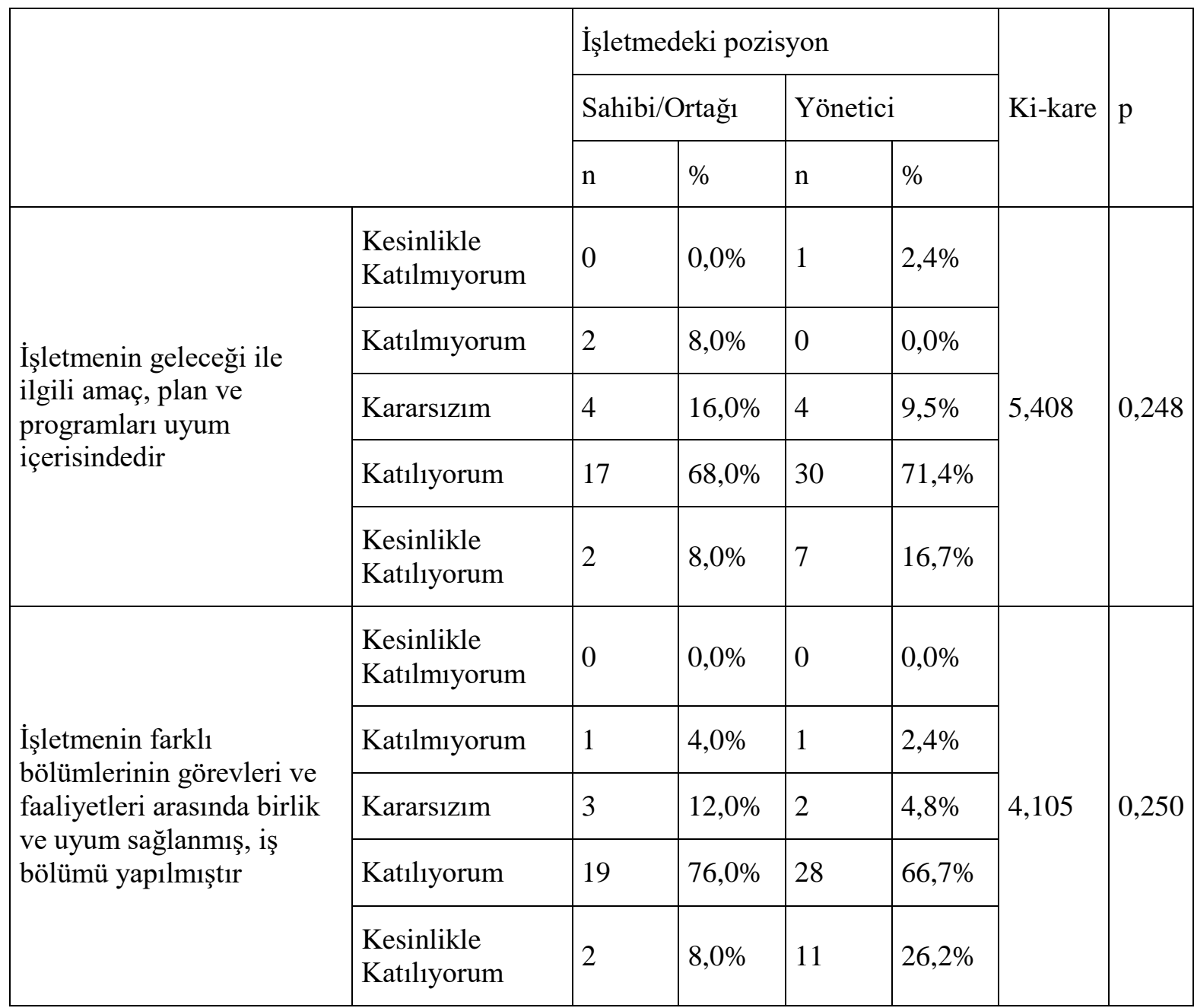

Ki-kare analizi sonuçlarına göre koordinasyon ile ilgili ifadelere katılım düzeyi ile işletmedeki pozisyon arasında anlamlı düzeyde ilişki bulunmamaktadır ( $\mathrm{p}>0,05)$.

Kontrol ile ilgili ifadelere katılım düzeyinin işletmedeki pozisyon ile ilişkisinin belirlenmesi için kikare analizi yapılmıştır. 
$\mathrm{H}_{10}:$ Kontrol sorunları ile ilgili algı düzeyi katılımcıların işletmedeki pozisyonuna göre anlamlı farklılık göstermektedir.

Tablo 10. Kontrol İle İlgili Iffadelere Katılım Düzeyinin Isşletmedeki Pozisyon İle İlişskisi

\begin{tabular}{|c|c|c|c|c|c|c|c|}
\hline & & \multicolumn{4}{|c|}{ İşletmedeki pozisyon } & \multirow{3}{*}{ Ki-kare } & \multirow{3}{*}{$\mathrm{p}$} \\
\hline & & \multicolumn{2}{|c|}{ Sahibi/Ortağ́1 } & \multicolumn{2}{|c|}{ Yönetici } & & \\
\hline & & $\mathrm{n}$ & $\%$ & $\mathrm{n}$ & $\%$ & & \\
\hline \multirow{5}{*}{$\begin{array}{l}\text { Denetimde yazılı belgeler, } \\
\text { istatistiki veriler, raporlar } \\
\text { ve analizler dikkate alınır }\end{array}$} & $\begin{array}{l}\text { Kesinlikle } \\
\text { Katılmiyorum }\end{array}$ & 0 & $0,0 \%$ & 1 & $2,4 \%$ & \multirow{5}{*}{11,268} & \multirow{5}{*}{$0,024 *$} \\
\hline & Katılmiyorum & 4 & $16,0 \%$ & 0 & $0,0 \%$ & & \\
\hline & Kararsızım & 4 & $16,0 \%$ & 5 & $11,9 \%$ & & \\
\hline & Kat1liyorum & 16 & $64,0 \%$ & 26 & $61,9 \%$ & & \\
\hline & $\begin{array}{l}\text { Kesinlikle } \\
\text { Kat1liyorum }\end{array}$ & 1 & $4,0 \%$ & 10 & $23,8 \%$ & & \\
\hline \multirow{5}{*}{$\begin{array}{l}\text { İşletme denetim sürecini } \\
\text { kendi düşünce ve } \\
\text { yorumlarıma göre } \\
\text { gerçekleştiririm }\end{array}$} & $\begin{array}{l}\text { Kesinlikle } \\
\text { Katılmıyorum }\end{array}$ & 2 & $8,0 \%$ & 3 & $7,1 \%$ & \multirow{5}{*}{7,565} & \multirow{5}{*}{0,109} \\
\hline & Katılmiyorum & 2 & $8,0 \%$ & 10 & $23,8 \%$ & & \\
\hline & Kararsızım & 3 & $12,0 \%$ & 12 & $28,6 \%$ & & \\
\hline & Kat1liyorum & 17 & $68,0 \%$ & 15 & $35,7 \%$ & & \\
\hline & $\begin{array}{l}\text { Kesinlikle } \\
\text { Katıliyorum }\end{array}$ & 1 & $4,0 \%$ & 2 & $4,8 \%$ & & \\
\hline
\end{tabular}

$* \mathrm{p}<0,05$

Ki-kare analizi sonuçlarına göre; "Denetimde yazılı belgeler, istatistiki veriler, raporlar ve analizler dikkate alınır" ifadesine katılım düzeyi ile işletmedeki pozisyon arasında anlamlı düzeyde ilişki bulunmaktadır $(\mathrm{p}<0,05)$.

"Denetimde yazılı belgeler, istatistikî veriler, raporlar ve analizler dikkate alınır" ifadesine işletme sahibi/ortağı olanlardan, katılmayanların oranı \%16, kararsızların oranı ise \%16'dır. Katılıyorum cevab1 verenlerin oran1 \%64 iken kesinlikle katıllyorum cevab1 verenlerin oranı \%4'tür. Yönetici olanlardan kesinlikle katılmayanların oranı \%2,4, kararsızların oranı ise \%11,9'dur. Katıliyorum cevab1 verenlerin oran1 \%61,9 iken kesinlikle katıliyorum cevab1 verenlerin oranı $\% 23,8$ 'dir.

$\mathrm{H}_{11}:$ Pazarlama sorunları ile ilgili algı düzeyi katılımcıların işletmedeki pozisyonuna göre anlamlı farkl111k göstermektedir.

Pazarlama ile ilgili ifadelere katılım düzeyinin işletmedeki pozisyon ile ilişkisinin belirlenmesi için kikare analizi yapılmıştır.

Tablo 11. Pazarlama İle İlgili İfadelere Katılım Düzeyinin İsletmedeki Pozisyon İle İlişkisi

\begin{tabular}{|l|l|l|l|}
\hline & İşletmedeki pozisyon & Ki-kare & $\mathrm{p}$ \\
\hline
\end{tabular}




\begin{tabular}{|c|c|c|c|c|c|c|c|}
\hline & & & Ortağ 1 & Yö & & & \\
\hline & & $\mathrm{n}$ & $\%$ & $\mathrm{n}$ & $\%$ & & \\
\hline & $\begin{array}{l}\text { Kesinlikle } \\
\text { Kat1liyorum }\end{array}$ & 1 & $4,0 \%$ & 2 & $4,8 \%$ & & \\
\hline & Kat1liyorum & 7 & $28,0 \%$ & 9 & $21,4 \%$ & & \\
\hline $\begin{array}{l}\text { Pazar bulma güçlüğü } \\
\text { çekmekteyiz }\end{array}$ & Fikrim Yok & 2 & $8,0 \%$ & 8 & $19,0 \%$ & 1,776 & 0,777 \\
\hline & Katılmiyorum & 13 & $52,0 \%$ & 19 & $45,2 \%$ & & \\
\hline & $\begin{array}{l}\text { Kesinlikle } \\
\text { Katılmıyorum }\end{array}$ & 2 & $8,0 \%$ & 4 & $9,5 \%$ & & \\
\hline & $\begin{array}{l}\text { Kesinlikle } \\
\text { Katılıyorum }\end{array}$ & 1 & $4,0 \%$ & 2 & $4,8 \%$ & & \\
\hline & Kat1liyorum & 2 & $8,0 \%$ & 3 & $7,1 \%$ & & \\
\hline $\begin{array}{l}\text { Yoğun rekabet ortamından } \\
\text { etkilenmekteviz }\end{array}$ & Fikrim Yok & 4 & $16,0 \%$ & 5 & $11,9 \%$ & 1,043 & 0,903 \\
\hline & Kat1lmiyorum & 12 & $48,0 \%$ & 25 & $59,5 \%$ & & \\
\hline & $\begin{array}{l}\text { Kesinlikle } \\
\text { Katılmıyorum }\end{array}$ & 6 & $24,0 \%$ & 7 & $16,7 \%$ & & \\
\hline & $\begin{array}{l}\text { Kesinlikle } \\
\text { Katıliyorum }\end{array}$ & 0 & $0,0 \%$ & 2 & $4,8 \%$ & & \\
\hline & Kat1liyorum & 3 & $12,0 \%$ & 1 & $2,4 \%$ & & \\
\hline istikrarsızlığından & Fikrim Yok & 1 & $4,0 \%$ & 3 & $7,1 \%$ & 4,338 & 0,362 \\
\hline & Katılmiyorum & 14 & $56,0 \%$ & 27 & $64,3 \%$ & & \\
\hline & $\begin{array}{l}\text { Kesinlikle } \\
\text { Katılmiyorum }\end{array}$ & 7 & $28,0 \%$ & 9 & $21,4 \%$ & & \\
\hline & $\begin{array}{l}\text { Kesinlikle } \\
\text { Kat1liyorum }\end{array}$ & 1 & $4,0 \%$ & 4 & $9,5 \%$ & & \\
\hline & Katıliyorum & 6 & $24,0 \%$ & 14 & $33,3 \%$ & & \\
\hline $\begin{array}{l}\text { Kalite düşüklüğü ile oluşan } \\
\text { problemler yasamaktaviz }\end{array}$ & Fikrim Yok & 5 & $20,0 \%$ & 7 & $16,7 \%$ & 1,981 & 0,739 \\
\hline & Katılmiyorum & 11 & $44,0 \%$ & 13 & $31,0 \%$ & & \\
\hline & $\begin{array}{l}\text { Kesinlikle } \\
\text { Katılmiyorum }\end{array}$ & 2 & $8,0 \%$ & 4 & $9,5 \%$ & & \\
\hline Yetersiz reklam ve & Kesinlikle & 2 & $8,0 \%$ & 2 & $4,8 \%$ & 1,247 & 0,87 \\
\hline
\end{tabular}




\begin{tabular}{|c|c|c|c|c|c|c|c|}
\hline \multirow{5}{*}{$\begin{array}{l}\text { promosyondan } \\
\text { etkilenmekteyiz }\end{array}$} & \multicolumn{5}{|l|}{ Katıliyorum } & & \\
\hline & Katıliyorum & 6 & $24,0 \%$ & 12 & $28,6 \%$ & & \\
\hline & Fikrim Yok & 4 & $16,0 \%$ & 7 & $16,7 \%$ & & \\
\hline & Katılmiyorum & 12 & $48,0 \%$ & 17 & $40,5 \%$ & & \\
\hline & $\begin{array}{l}\text { Kesinlikle } \\
\text { Katılmıyorum }\end{array}$ & 1 & $4,0 \%$ & 4 & $9,5 \%$ & & \\
\hline \multirow{5}{*}{$\begin{array}{l}\text { Dağıtım kanallarıyla ilgili } \\
\text { problemler yaşamaktayız }\end{array}$} & $\begin{array}{l}\text { Kesinlikle } \\
\text { Katılıyorum }\end{array}$ & 1 & $4,0 \%$ & 4 & $9,5 \%$ & \multirow{5}{*}{2,444} & \multirow{5}{*}{0,655} \\
\hline & Katıliyorum & 7 & $28,0 \%$ & 7 & $16,7 \%$ & & \\
\hline & Fikrim Yok & 6 & $24,0 \%$ & 12 & $28,6 \%$ & & \\
\hline & Katılmiyorum & 10 & $40,0 \%$ & 15 & $35,7 \%$ & & \\
\hline & $\begin{array}{l}\text { Kesinlikle } \\
\text { Katılmıyorum }\end{array}$ & 1 & $4,0 \%$ & 4 & $9,5 \%$ & & \\
\hline \multirow{5}{*}{$\begin{array}{l}\text { Satış elemanlarının etkin } \\
\text { olmamasından dolayı } \\
\text { problem yaşamaktayız }\end{array}$} & $\begin{array}{l}\text { Kesinlikle } \\
\text { Kat1liyorum }\end{array}$ & 1 & $4,0 \%$ & 4 & $9,5 \%$ & \multirow{5}{*}{2,332} & \multirow{5}{*}{0,675} \\
\hline & Kat1liyorum & 9 & $36,0 \%$ & 15 & $35,7 \%$ & & \\
\hline & Fikrim Yok & 3 & $12,0 \%$ & 9 & $21,4 \%$ & & \\
\hline & Katılmiyorum & 9 & $36,0 \%$ & 10 & $23,8 \%$ & & \\
\hline & $\begin{array}{l}\text { Kesinlikle } \\
\text { Katılmıyorum }\end{array}$ & 3 & $12,0 \%$ & 4 & $9,5 \%$ & & \\
\hline \multirow{5}{*}{$\begin{array}{l}\text { Ambalajlama ve paketleme } \\
\text { sorunları yaşamaktayız }\end{array}$} & $\begin{array}{l}\text { Kesinlikle } \\
\text { Katıliyorum }\end{array}$ & 2 & $8,0 \%$ & 5 & $11,9 \%$ & \multirow{5}{*}{3,652} & \multirow{5}{*}{0,455} \\
\hline & Katıliyorum & 5 & $20,0 \%$ & 13 & $31,0 \%$ & & \\
\hline & Fikrim Yok & 8 & $32,0 \%$ & 10 & $23,8 \%$ & & \\
\hline & Katılmıyorum & 9 & $36,0 \%$ & 9 & $21,4 \%$ & & \\
\hline & $\begin{array}{l}\text { Kesinlikle } \\
\text { Katılmıyorum }\end{array}$ & 1 & $4,0 \%$ & 5 & $11,9 \%$ & & \\
\hline \multirow{3}{*}{$\begin{array}{l}\text { Markalaşma konusunda } \\
\text { zorluk çekiyoruz }\end{array}$} & $\begin{array}{l}\text { Kesinlikle } \\
\text { Katıliyorum }\end{array}$ & 2 & $8,0 \%$ & 6 & $14,3 \%$ & \multirow{3}{*}{3,983} & \multirow{3}{*}{0,408} \\
\hline & Katıliyorum & 6 & $24,0 \%$ & 14 & $33,3 \%$ & & \\
\hline & Fikrim Yok & 3 & $12,0 \%$ & 6 & $14,3 \%$ & & \\
\hline
\end{tabular}




\begin{tabular}{|c|c|c|c|c|c|c|c|}
\hline & Katılmiyorum & 13 & $52,0 \%$ & 12 & $28,6 \%$ & & \\
\hline & $\begin{array}{l}\text { Kesinlikle } \\
\text { Katılmıyorum }\end{array}$ & 1 & $4,0 \%$ & 4 & $9,5 \%$ & & \\
\hline \multirow{5}{*}{$\begin{array}{l}\text { Hammadde temininde } \\
\text { zorluk çekmekteyiz }\end{array}$} & $\begin{array}{l}\text { Kesinlikle } \\
\text { Katılıyorum }\end{array}$ & 2 & $8,0 \%$ & 2 & $4,8 \%$ & \multirow{5}{*}{2,707} & \multirow{5}{*}{0,608} \\
\hline & Katıliyorum & 5 & $20,0 \%$ & 9 & $21,4 \%$ & & \\
\hline & Fikrim Yok & 5 & $20,0 \%$ & 12 & $28,6 \%$ & & \\
\hline & Katılmiyorum & 12 & $48,0 \%$ & 14 & $33,3 \%$ & & \\
\hline & $\begin{array}{l}\text { Kesinlikle } \\
\text { Katılmiyorum }\end{array}$ & 1 & $4,0 \%$ & 5 & $11,9 \%$ & & \\
\hline
\end{tabular}

Ki-kare analizi sonuçlarına göre pazarlama ile ilgili ifadelere katılım düzeyi ile işletmedeki pozisyon arasında anlamlı düzeyde ilişki bulunmamaktadır ( $>0,05)$.

Üretim ile ilgili sorun yaşama düzeyinin işletmedeki pozisyon ile ilişkisinin belirlenmesi için ki-kare analizi yapılmıştır.

$\mathrm{H}_{12}:$ Üretim sorunları ile ilgili algı düzeyi katılımcıların işletmedeki pozisyonuna göre anlamlı farklılık göstermektedir.

Tablo 12. Üretim İle İlgili Yaşanan Sorun Düzeyinin Işsletmedeki Pozisyon İle İlişskisi

\begin{tabular}{|c|c|c|c|c|c|c|c|}
\hline & & \multicolumn{4}{|c|}{ İşletmedeki pozisyon } & \multirow{3}{*}{ Ki-kare } & \multirow{3}{*}{$\mathrm{p}$} \\
\hline & & \multicolumn{2}{|c|}{ Sahibi/Ortağ1 } & \multicolumn{2}{|c|}{ Yönetici } & & \\
\hline & & $\mathrm{n}$ & $\%$ & $\mathrm{n}$ & $\%$ & & \\
\hline \multirow{5}{*}{$\begin{array}{l}\text { Yerli ve ithal hammadde } \\
\text { yetersizlikleri }\end{array}$} & $\begin{array}{ll}\text { Çok } & \text { sorun } \\
\text { yaşıyoruz } & \end{array}$ & 1 & $4,0 \%$ & 5 & $11,9 \%$ & \multirow{5}{*}{3,325} & \multirow{5}{*}{0,344} \\
\hline & Yaşıyoruz & 14 & $56,0 \%$ & 19 & $45,2 \%$ & & \\
\hline & Kararsızım & 1 & $4,0 \%$ & 6 & $14,3 \%$ & & \\
\hline & Pek yaşamıyoruz & 9 & $36,0 \%$ & 12 & $28,6 \%$ & & \\
\hline & $\begin{array}{l}\text { Hiç sorun } \\
\text { yaşamıyoruz }\end{array}$ & 0 & $0,0 \%$ & 0 & $0,0 \%$ & & \\
\hline \multirow{4}{*}{$\begin{array}{l}\text { Hammadde tedarik } \\
\text { süresinin uzun olması }\end{array}$} & $\begin{array}{ll}\text { Çok } & \text { sorun } \\
\text { yaşıyoruz } & \end{array}$ & 0 & $0,0 \%$ & 3 & $7,1 \%$ & \multirow{4}{*}{3,712} & \multirow{4}{*}{0,294} \\
\hline & Yaşıyoruz & 14 & $56,0 \%$ & 19 & $45,2 \%$ & & \\
\hline & Kararsızım & 2 & $8,0 \%$ & 8 & $19,0 \%$ & & \\
\hline & Pek yaşamıyoruz & 9 & $36,0 \%$ & 12 & $28,6 \%$ & & \\
\hline
\end{tabular}




\begin{tabular}{|c|c|c|c|c|c|c|c|}
\hline & \begin{tabular}{|l|} 
Hiç sorun \\
yaşamıyoruz
\end{tabular} & 0 & $0,0 \%$ & 0 & $0,0 \%$ & & \\
\hline \multirow{5}{*}{$\begin{array}{l}\text { Hammadde maliyetlerinin } \\
\text { yüksek olması }\end{array}$} & 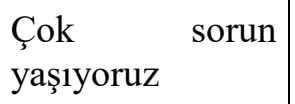 & 3 & $12,0 \%$ & 13 & $31,0 \%$ & \multirow{5}{*}{6,917} & \multirow{5}{*}{0,075} \\
\hline & Yaşıyoruz & 16 & $64,0 \%$ & 20 & $47,6 \%$ & & \\
\hline & Kararsızım & 0 & $0,0 \%$ & 4 & $9,5 \%$ & & \\
\hline & Pek yaşamıyoruz & 6 & $24,0 \%$ & 5 & $11,9 \%$ & & \\
\hline & \begin{tabular}{|l|} 
Hiç sorun \\
yaşamıyoruz
\end{tabular} & 0 & $0,0 \%$ & 0 & $0,0 \%$ & & \\
\hline \multirow{5}{*}{$\begin{array}{l}\text { Üretim teknolojisinin eski } \\
\text { olması }\end{array}$} & 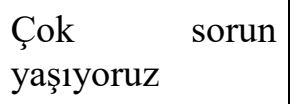 & 1 & $4,0 \%$ & 4 & $9,5 \%$ & \multirow{5}{*}{3,752} & \multirow{5}{*}{0,289} \\
\hline & Yaşıyoruz & 12 & $48,0 \%$ & 16 & $38,1 \%$ & & \\
\hline & Kararsızım & 3 & $12,0 \%$ & 12 & $28,6 \%$ & & \\
\hline & Pek yaşamıyoruz & 9 & $36,0 \%$ & 10 & $23,8 \%$ & & \\
\hline & $\begin{array}{l}\text { Hiç sorun } \\
\text { yaşamıyoruz }\end{array}$ & 0 & $0,0 \%$ & 0 & $0,0 \%$ & & \\
\hline \multirow{5}{*}{ Kalifiye eleman yetersizliği } & $\begin{array}{|ll|}\text { Çok } & \text { sorun } \\
\text { yaşıyoruz } & \end{array}$ & 3 & $12,0 \%$ & 7 & $16,7 \%$ & \multirow{5}{*}{1,66} & \multirow{5}{*}{0,646} \\
\hline & Yaşıyoruz & 15 & $60,0 \%$ & 21 & $50,0 \%$ & & \\
\hline & Kararsızım & 1 & $4,0 \%$ & 5 & $11,9 \%$ & & \\
\hline & Pek yaşamıyoruz & 6 & $24,0 \%$ & 9 & $21,4 \%$ & & \\
\hline & \begin{tabular}{|l|} 
Hiç sorun \\
yaşamıyoruz
\end{tabular} & 0 & $0,0 \%$ & 0 & $0,0 \%$ & & \\
\hline \multirow{5}{*}{$\begin{array}{l}\text { Üründe istenen kalite } \\
\text { standardını karşılayamama }\end{array}$} & 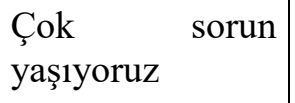 & 0 & $0,0 \%$ & 4 & $9,5 \%$ & \multirow{5}{*}{4,186} & \multirow{5}{*}{0,242} \\
\hline & Yaşıyoruz & 13 & $52,0 \%$ & 15 & $35,7 \%$ & & \\
\hline & Kararsızım & 3 & $12,0 \%$ & 9 & $21,4 \%$ & & \\
\hline & Pek yaşamıyoruz & 9 & $36,0 \%$ & 14 & $33,3 \%$ & & \\
\hline & $\begin{array}{l}\text { Hiç sorun } \\
\text { yaşamıyoruz }\end{array}$ & 0 & $0,0 \%$ & 0 & $0,0 \%$ & & \\
\hline Stoklardaki artışlar & 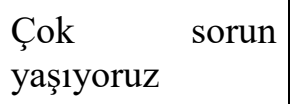 & 1 & $4,0 \%$ & 5 & $11,9 \%$ & 11,809 & $0,008 *$ \\
\hline
\end{tabular}




\begin{tabular}{|c|c|c|c|c|c|c|c|}
\hline & Yaşıyoruz & 18 & $72,0 \%$ & 13 & $31,0 \%$ & & \\
\hline & Kararsızım & 1 & $4,0 \%$ & 11 & $26,2 \%$ & & \\
\hline & Pek yaşamıyoruz & 5 & $20,0 \%$ & 13 & $31,0 \%$ & & \\
\hline & $\begin{array}{l}\text { Hiç sorun } \\
\text { yaşamıyoruz }\end{array}$ & 0 & $0,0 \%$ & 0 & $0,0 \%$ & & \\
\hline \multirow{5}{*}{ Teslimatta gecikmeler } & $\begin{array}{ll}\text { Çok } & \text { sorun } \\
\text { yaşıyoruz } & \end{array}$ & 0 & $0,0 \%$ & 3 & $7,1 \%$ & \multirow{5}{*}{2,338} & \multirow{5}{*}{0,505} \\
\hline & Yaşıyoruz & 11 & $44,0 \%$ & 15 & $35,7 \%$ & & \\
\hline & Kararsızım & 3 & $12,0 \%$ & 7 & $16,7 \%$ & & \\
\hline & Pek yaşamıyoruz & 11 & $44,0 \%$ & 17 & $40,5 \%$ & & \\
\hline & $\begin{array}{l}\text { Hiç sorun } \\
\text { yaşamıyoruz }\end{array}$ & 0 & $0,0 \%$ & 0 & $0,0 \%$ & & \\
\hline \multirow{5}{*}{$\begin{array}{l}\text { Kapasite kullanımı ile ilgili } \\
\text { sorunlar }\end{array}$} & $\begin{array}{ll}\text { Çok } & \text { sorun } \\
\text { yaşıyoruz } & \end{array}$ & 1 & $4,0 \%$ & 5 & $11,9 \%$ & \multirow{5}{*}{4,757} & \multirow{5}{*}{0,190} \\
\hline & Yaşıyoruz & 13 & $52,0 \%$ & 14 & $33,3 \%$ & & \\
\hline & Kararsızım & 2 & $8,0 \%$ & 10 & $23,8 \%$ & & \\
\hline & Pek yaşamıyoruz & 9 & $36,0 \%$ & 13 & $31,0 \%$ & & \\
\hline & $\begin{array}{l}\text { Hiç sorun } \\
\text { yaşamıyoruz }\end{array}$ & 0 & $0,0 \%$ & 0 & $0,0 \%$ & & \\
\hline
\end{tabular}

$* \mathrm{p}<0,05$

Ki-kare analizi sonuçlarına göre; "stoklardaki artışlar" ile ilgili sorun yaşama düzeyi ile işletmedeki pozisyon arasında anlamlı düzeyde ilişki bulunmaktadır. İşletme sahibi/ortağı olanlardan "stoklardaki artışlar" ile ilgili çok sorun yaşadığını belirtenlerin oranı $\% 4$, sorun yaşadığını belirtenlerin oranı $\% 72$, kararsız olanların oranı \%4'tür. Pek sorun yaşamadığını belirtenlerin oranı $\% 20$ oranındadır. Yöneticilerden çok sorun yaşadığını belirtenlerin oranı \%11,9, sorun yaşadığını belirtenlerin oranı $\% 31$, kararsız olanların oran $\% 26,2$ 'dir. Pek sorun yaşamadığını belirtenler ise $\% 31$ oranındadır.

Finans ile ilgili sorun yaşama düzeyinin işletmedeki pozisyon ile ilişkisinin belirlenmesi için ki-kare analizi yapılmıştır.

$\mathrm{H}_{13}$ :Finans sorunlanı ile ilgili algı düzeyi katılımcıların işletmedeki pozisyonuna göre anlamlı farklılık göstermektedir. 
Tablo 13. Finans İle İlgili Yaşanan Sorun Düzeyinin İşletmedeki Pozisyon İle İlişkisi

\begin{tabular}{|c|c|c|c|c|c|c|c|}
\hline & \multicolumn{4}{|c|}{ İşletmedeki pozisyon } & \multirow{3}{*}{ Ki-kare } & \multirow{3}{*}{$\mathrm{p}$} \\
\hline & & \multicolumn{2}{|c|}{ Sahibi/Ortağ1 } & \multicolumn{2}{|c|}{ Yönetici } & & \\
\hline & & $\mathrm{n}$ & $\%$ & $\mathrm{n}$ & $\%$ & & \\
\hline \multirow{5}{*}{ Kredi bulamamak } & Hiç önemli değil & 3 & $12,0 \%$ & 2 & $4,8 \%$ & \multirow{5}{*}{6,743} & \multirow{5}{*}{0,150} \\
\hline & Önemli değil & 1 & $4,0 \%$ & 5 & $11,9 \%$ & & \\
\hline & Kısmen önemli & 4 & $16,0 \%$ & 14 & $33,3 \%$ & & \\
\hline & Önemli & 6 & $24,0 \%$ & 12 & $28,6 \%$ & & \\
\hline & Çok önemli & 11 & $44,0 \%$ & 9 & $21,4 \%$ & & \\
\hline \multirow{5}{*}{$\begin{array}{l}\text { Kredi maliyetinin } \\
\text { yüksekliği }\end{array}$} & Hiç önemli değil & 3 & $12,0 \%$ & 2 & $4,8 \%$ & \multirow{5}{*}{2,98} & \multirow{5}{*}{0,561} \\
\hline & Önemli değil & 1 & $4,0 \%$ & 1 & $2,4 \%$ & & \\
\hline & Kısmen önemli & 1 & $4,0 \%$ & 6 & $14,3 \%$ & & \\
\hline & Önemli & 8 & $32,0 \%$ & 15 & $35,7 \%$ & & \\
\hline & Çok önemli & 12 & $48,0 \%$ & 18 & $42,9 \%$ & & \\
\hline \multirow{5}{*}{$\begin{array}{l}\text { Alacakların zamaninda } \\
\text { tahsil edilememesi }\end{array}$} & Hiç önemli değil & 0 & $0,0 \%$ & 0 & $0,0 \%$ & \multirow{5}{*}{0,876} & \multirow{5}{*}{0,645} \\
\hline & Önemli değil & 0 & $0,0 \%$ & 0 & $0,0 \%$ & & \\
\hline & Kısmen önemli & 4 & $16,0 \%$ & 4 & $9,5 \%$ & & \\
\hline & Önemli & 8 & $32,0 \%$ & 12 & $28,6 \%$ & & \\
\hline & Çok önemli & 13 & $52,0 \%$ & 26 & $61,9 \%$ & & \\
\hline \multirow{5}{*}{$\begin{array}{l}\text { İşletme sermayesi } \\
\text { yetersizliği }\end{array}$} & Hiç önemli değil & 1 & $4,0 \%$ & 1 & $2,4 \%$ & \multirow{5}{*}{6,727} & \multirow{5}{*}{0,151} \\
\hline & Önemli değil & 1 & $4,0 \%$ & 1 & $2,4 \%$ & & \\
\hline & Kısmen önemli & 2 & $8,0 \%$ & 11 & $26,2 \%$ & & \\
\hline & Önemli & 10 & $40,0 \%$ & 21 & $50,0 \%$ & & \\
\hline & Çok önemli & 11 & $44,0 \%$ & 8 & $19,0 \%$ & & \\
\hline \multirow{3}{*}{ Öz kaynakların yetersizliği } & Hiç önemli değil & 1 & $4,0 \%$ & 1 & $2,4 \%$ & \multirow{3}{*}{4,259} & \multirow{3}{*}{0,372} \\
\hline & Önemli değil & 2 & $8,0 \%$ & 2 & $4,8 \%$ & & \\
\hline & Kısmen önemli & 3 & $12,0 \%$ & 10 & $23,8 \%$ & & \\
\hline
\end{tabular}




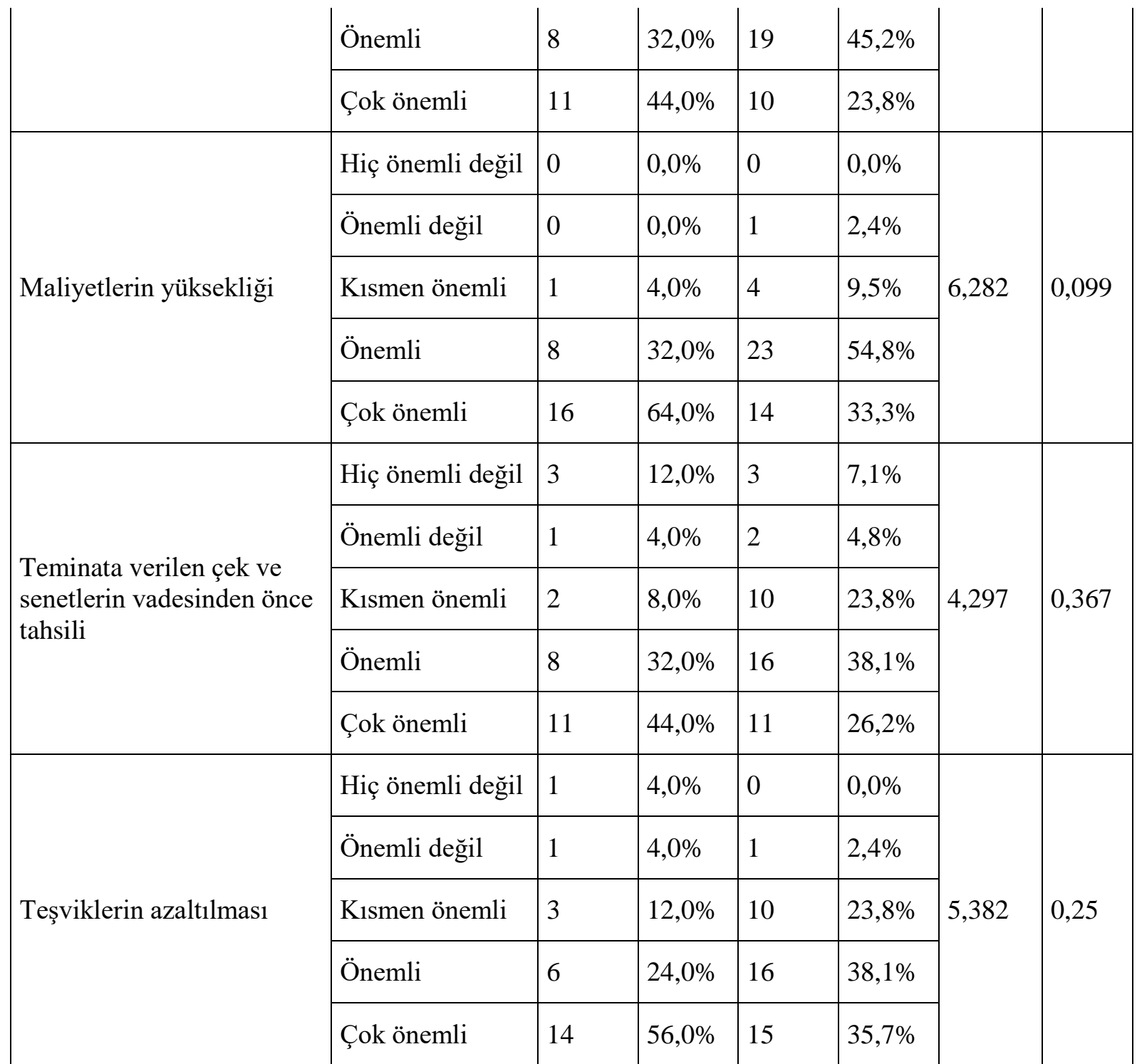

Ki-kare analizi sonuçlarına göre finans ile ilgili sorun yaşama düzeyi ile işletmedeki pozisyon arasında anlamlı düzeyde ilişki bulunmamaktadır ( $\mathrm{p}>0,05)$.

Performans ile ilgili ifadelerin önem düzeyinin işletmedeki pozisyon ile ilişkisinin belirlenmesi için kikare analizi yapılmıştır.

$\mathrm{H}_{14}:$ İşletmenin genel performansı katılımcıların işletmedeki pozisyonuna göre anlamlı farklılık göstermektedir.

Tablo 14. Performans İle İlgili İfadelerin Önem Düzeyi İle İşletmedeki Pozisyon İle İlişkisi

\begin{tabular}{|c|c|c|c|c|c|c|c|}
\hline & & & leki pozi & yor & & & \\
\hline & & & rtağ & & & Ki-kare & $\mathrm{p}$ \\
\hline & & $\mathrm{n}$ & $\%$ & $\mathrm{n}$ & $\%$ & & \\
\hline & Çok düşük & 0 & $0,0 \%$ & 0 & $0,0 \%$ & & \\
\hline & Düşük & 4 & $16,0 \%$ & 3 & $7,1 \%$ & & \\
\hline
\end{tabular}




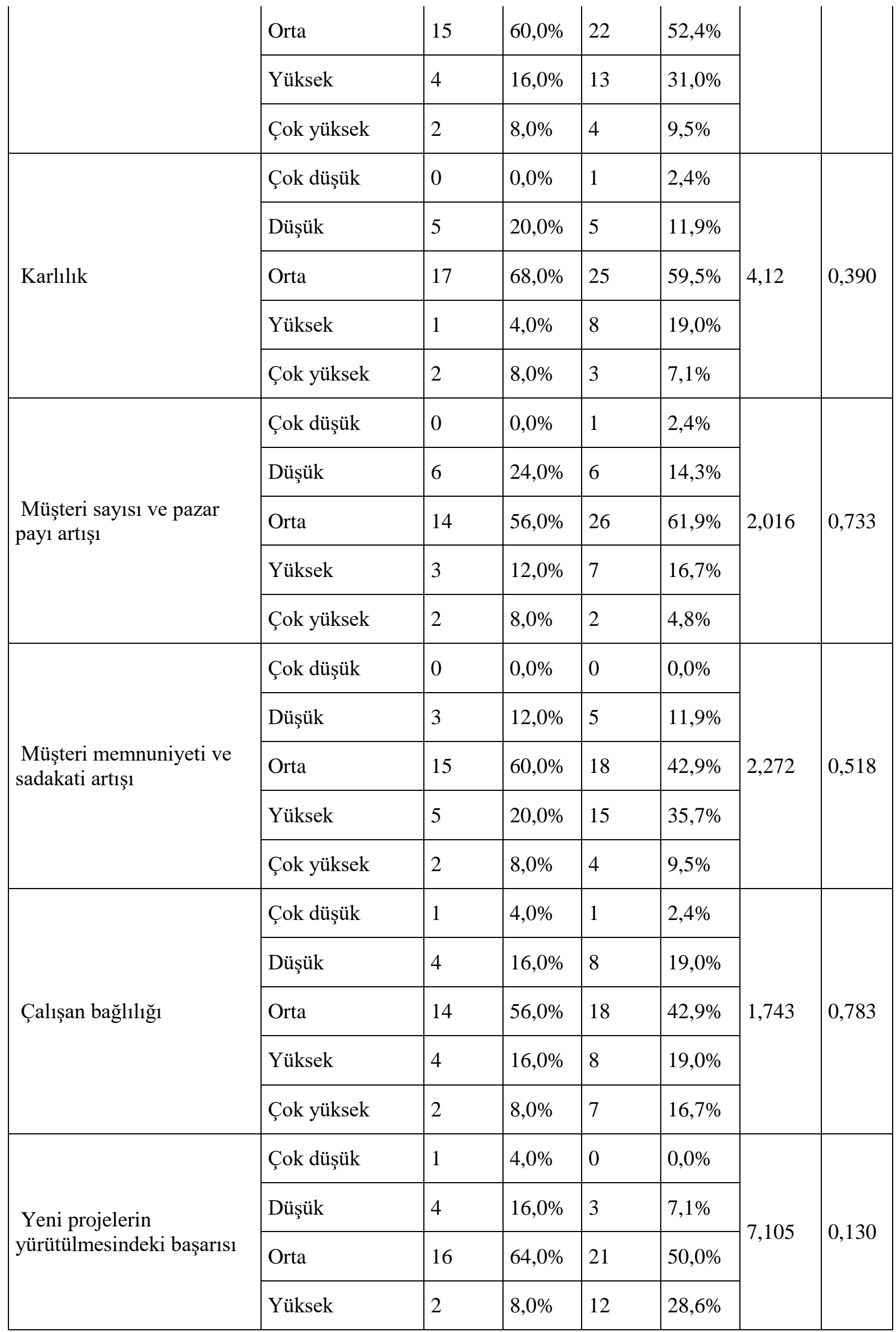




\begin{tabular}{|c|c|c|c|c|c|c|c|}
\hline & Çok yüksek & 2 & $8,0 \%$ & 6 & $14,3 \%$ & & \\
\hline \multirow{5}{*}{$\begin{array}{l}\text { Yeni ürün (hizmet) } \\
\text { geliştirme başarısı }\end{array}$} & Çok düşük & 1 & $4,0 \%$ & 0 & $0,0 \%$ & \multirow{5}{*}{6,829} & \multirow{5}{*}{0,145} \\
\hline & Düşük & 6 & $24,0 \%$ & 4 & $9,5 \%$ & & \\
\hline & Orta & 13 & $52,0 \%$ & 19 & $45,2 \%$ & & \\
\hline & Yüksek & 3 & $12,0 \%$ & 12 & $28,6 \%$ & & \\
\hline & Çok yüksek & 2 & $8,0 \%$ & 7 & $16,7 \%$ & & \\
\hline \multirow{5}{*}{ İşgücü devir oranı } & Çok düşük & 1 & $4,0 \%$ & 0 & $0,0 \%$ & \multirow{5}{*}{6,089} & \multirow{5}{*}{0,193} \\
\hline & Düşük & 6 & $24,0 \%$ & 6 & $14,3 \%$ & & \\
\hline & Orta & 15 & $60,0 \%$ & 22 & $52,4 \%$ & & \\
\hline & Yüksek & 1 & $4,0 \%$ & 9 & $21,4 \%$ & & \\
\hline & Çok yüksek & 2 & $8,0 \%$ & 5 & $11,9 \%$ & & \\
\hline \multirow{5}{*}{$\begin{array}{l}\text { Genel performans1 ve } \\
\text { başarıs1 }\end{array}$} & Çok düşük & 1 & $4,0 \%$ & 0 & $0,0 \%$ & \multirow{5}{*}{5,593} & \multirow{5}{*}{0,232} \\
\hline & Düşük & 5 & $20,0 \%$ & 3 & $7,1 \%$ & & \\
\hline & Orta & 14 & $56,0 \%$ & 23 & $54,8 \%$ & & \\
\hline & Yüksek & 3 & $12,0 \%$ & 11 & $26,2 \%$ & & \\
\hline & Çok yüksek & 2 & $8,0 \%$ & 5 & $11,9 \%$ & & \\
\hline
\end{tabular}

Ki-kare analizi sonuçlarına göre; performans ile ilgili ifadelerin önem düzeyi ile işletmedeki pozisyon arasında anlamlı düzeyde ilişki bulunmamaktadır $(\mathrm{p}>0,05)$.

\section{SONUC VE ÖNERILER}

KOBİ'lerin işletme fonksiyonları açısından karşılaştıkları sorunların ve performansa etkilerinin incelenmesi amacıyla yapılan araştırmanın sonuçlarına göre; içinde bulunulan koşullar (ekonomik kriz, siyasal istikrarsızlık) ve işletmede planlama yapacak uzman bulunmaması planlama fonksiyonuna ilişkin yaşanan sorunlar olarak belirlenmiştir. Organizasyon fonksiyonuna ilişkin olarak, işletmelerin yaklaşık yarısında aileden olmayan yöneticilerin yetki ve sorumluluklarının sınırlı olması ve işletmelerin bir kısmında ise yönetimin profesyonel yöneticilere devredilmemesi sorunları görülmektedir. KOBİ'lerde emirlerin sözlü olarak verilmesi sorununun varlığını katılımcı işletmelerin yarıdan fazlası tarafından kabul edilmiştir. Çalışanların karşılık beklemeksizin her türlü emri yerine getirmek zorunda olmaları bir sorun olarak algılanmaktadır. KOBİ'lerin koordinasyon fonksiyonuna yönelik olarak genel olarak bir sorun yaşanmadığı tespit edilmiştir. İşletmedeki denetim sürecinin kişinin kendi düşünce ve yorumlarına göre gerçekleştirilmesi sorununun varlığını ise katılımcı işletmelerin sahip/yöneticilerinin yaklaşık yarısı tarafından desteklenmiştir. Yönetim fonksiyonu konusunda yaşanan bu tür sorunların araştırma yapılan KOBI'lerin \%53,7'sinin aile işletmesi olması ve üst düzeyde çalışan aile üyesinin $\% 55,9$ oranında olması önemli bir etken olduğu şeklinde değerlendirilmiştir. Yoğun rekabet ortamından ve piyasadaki fiyat istikrarsızlığından etkilenme, pazar bulma güçlüğü çekmeleri, dağıtım kanalları, yetersiz reklam ve promosyondan etkilenmeleri, satış elemanlarının etkin olmaması, markalaşma konusunda işletmelerin yaşadığı öncelikli pazarlama sorunlarındandır. Yine işletmelerin yerli ve ithal hammadde yetersizlikleri, hammadde tedarik 
süresinin uzun olması, stoklardaki artışlar, üretim teknolojisinin eski olması, üründe istenen kalite standardının karşılanamaması, kapasite kullanımı, teslimatta gecikmeler, kalifiye eleman yetersizliği, ambalajlama-paketlemeyle ilgili kalite düşüklüğ̈̈ gibi konular işletmelerin yaşadığı öncelikli üretim sorunlarındandır. Çalışmadan elde edilen veriler doğrultusunda işletmeler, kredi bulamama ve kredi maliyetinin yüksekliğini, alacakların zamanında tahsil edilememesini, işletme sermayesi ve öz kaynakların yetersizliğini, maliyetlerin yüksekliğini, teşviklerin azaltılmasını önemli finansal sorun olarak belirtmişlerdir. Bu sorunların KOBİ'lerin performansı üzerinde etkili olduğu çalışmanın analiz kısmında da istatistiksel olarak ortaya konulmuştur.

$\mathrm{Bu}$ sorunların çözümüne katkı sağlayabileceği düşünülen birtakım öneriler sunulmuştur. Yönetim fonksiyonu kapsamında; KOBİ'ler için olağan bir planlama sürecinin dışında içinde bulunulan çevresel koşulların değişimine hızlı bir şekilde uyum sağlayabilecek stratejik planları hazırlamak önemli bir görevdir. Organizasyon kapsamında işletmelerin yönetimlerini profesyonel yöneticilere devretmekten kaçınmamaları gerekir. Bunu yaparken de aileden olmayan yöneticilerin yetki ve sorumluluk alanlarının sınırlı tutulmaması önemlidir. Yöneltme kapsamında işletmelerde kişilerin kimden emir alıp kime emir vereceği sözlü değil de yazılı olarak belirlenirse yöneticinin işletmede bulunmadığı durumlarda işlerin aksaması ve işin çalışan tarafindan yanlış anlaşılması engellenecektir. Yine başarılı ve verimli çalışana yaptığı katkı oranında maddi ve/veya manevi karşılıkların verilmesi çalışanların işi benimsemesini ve sahiplenmesini sağlar. Bunu yapılırken mutlaka performans ölçme ve değerleme sisteminin kullanılması daha uygun olacaktır. Ayrıca maddi ve/veya manevi karşılıklar verilerek ödüllendirilen çalışanların varlığı da diğer çalışanlar üzerinde pozitif etki bırakırken ayrıca çalışanların işe ve işletmeye olan bağlılığını arttırabilecektir. Koordinasyon kapsamında; işletmelerin genel olarak bir sorun yaşamadığı belirlenmiştir. İşletmelerin amaç, plan ve programlarının uyum içerisinde olmasının, farklı bölümlerinin görevleri ve faaliyetleri arasında birlik ve uyum sağlanmasının, iş bölümü yapılmasının önemli olduğu bilinmelidir. Denetim fonksiyonu kapsamında; denetim sürecinin kişinin kendi düşünce ve yorumlarına göre gerçekleştirilmesinin önüne geçmek için yazılı belgelere, istatistiki verilere, raporlara ve analizlere önem verilmelidir. Ayrıca denetimin çalışanları da kapsayacak şekilde ön denetim veya süreç esnasında yapılması doğru bir yaklaşım olacaktır. Pazarlama fonksiyonu kapsamında; KOBİ'lerin yoğun rekabet ortamında ayakta kalabilmeleri ve rekabet avantaji sağlayabilmeleri için e-ticaret gibi uygulamaları kullanmaları önemlidir. Yine sürekli olarak pazar araştırması yapmaları ve müşteri odaklı yöntemler kullanmaları yerinde bir yaklaşım olacaktır. Dağıtım kanalları ile ilgili sorun yaşamamak için kendi yapılarına uygun modern dağıtım kanalları kullanmalıdırlar. Yetersiz düzeyde yapılan reklam ve promosyon gibi tutundurma faaliyetleri ve markalaşma konularında alanında uzman kuruluşlardan ya da profesyonel yöneticilerden destek almaları ve bu faaliyet için gerekli bütçeyi ayırmalıdırlar. Üretim fonksiyonu kapsamında; işletmeler üretim kapasiteleri ve yapılarına göre en uygun stok miktarı belirleme yöntemini kullanmalı, tedarikçiler ile sürekli iletişim içerisinde olarak ihtiyaca göre hareket etmelidirler. Kalite güvence sistemlerini kurmaları ve standartlara uygunluk için işletmede gerekli düzenlemeleri yapmaları gerekmektedir. Üretim teknolojilerinin işletmenin yapısına ve çağın gereklerine göre değiştirilmesi de önemli bir husustur. Bu değişiklik ile hem kapasite kullanımı ile ilgili sorunların önüne geçilmesi hem de teslimatta gecikmeler yaşanmaması sağlanabilir. Finans fonksiyonu kapsamında; İlgili kamu kurumları tarafindan finansman ihtiyacı olan KOBİ'lere kolaylıklar sağlanarak uygun şartlarda devlet, özel bankalar ve finans kurumları aracıllğı̆yla destek verilmelidir. KOBI'lerin üretim, ihracat, yenilik ve yatırım yapma konularında vergi indiriminden prim desteğine kadar uygun olan tüm teşviklerden yararlandırılması gerekmektedir. Yine sorun olarak da belirlenen teşviklerin azaltılması yerine işletmelerin rekabette avantaj sağlayabilmeleri için teşviklerin artırılması gerekmektedir. KOBİ'lerde sermaye yapılarını sadece öz kaynaklarıyla finanse etmemeli, bunu yabancı kaynaklarla desteklemelidirler. Sonuç olarak, bu araştırma sınırlı sayıda işletme ile yapılmış bölgesel bir çalışma niteliğindedir. Fakat araştırma Türkiye genelinde bundan sonra yapılacak daha kapsamlı araştırmalar için önemli veri sağlayacağı düşünülmektedir. $\mathrm{Bu}$ araştırmanın sonuçları Tokat KOSGEB il müdürlüğü veri tabanına kayıtlı imalatçı KOBİlerden elde edilen verilerden yola çıkılarak hazırlanmış ve yorumlanmıştır. Dolayısıyla farklı bölge ve illerde yapılacak olan benzer çalışmaların sonuçları ile benzerlik göstermesi beklenmemelidir. 


\section{Bilgilendirme / Acknowledgement:}

1-Araştırmacıların katkı oranı eşittir.

2-Bu çalışma, birinci yazarın danışmanlığında ikinci yazarın hazırladığı yüksek lisans tezinden üretilmiştir.

3-Çalışma için veri toplanmasına katkıda bulunan Tokat ilindeki imalatçı KOBİ sahip ve yöneticilerine teşekkür ederiz.

4-Makalenin yazarları arasında çıkar çatışması bulunmamaktadır.

5-Makalemizde etik kurulu izni ve/veya yasal/özel izin alınmasını gerektiren bir durum yoktur.(Bu çalışmanın bulguları, 2020

yılından önce yapılan yüksek lisans tezi için toplanmış verilerin analizinden elde edilmiştir.)

6-Bu makalede araștırma ve yayın etiğine uyulmuştur.

\section{KAYNAKÇA}

Akbulut, Ö.(2007). KOBİlerin genel işletme sorunları ve pazarlama sorunları üzerine Sivas'ta bir uygulama. Yayımlanmamış yüksek lisans tezi, Cumhuriyet Üniversitesi, Sivas.

Akgemci, T.(2001).KOBİ'lerin temel sorunlart ve sağlanan destekler. Ankara: KOSGEB.

Alpugan, O.(1998).Küçük işletmeler kavramı, kuruluşu ve yönetimi. Ankara: Per Yayınları.

Altunıșık, R., Coşkun, R., Bayraktaroğlu, S., \& Yıldırım, E. (2010). Sosyal bilimlerde araștırma yöntemleri SPSS uygulamalı (6. Bask1). Sakarya: Sakarya Yayıncılık.

Asal, Ö.(2001).Küçük ve orta ölçekli işletmelerde üretim stratejilerini etkileyen etkenler ve KOBI'lerin sorunları: Bir alan araştırması. Yayımlanmamış yüksek lisans tezi, Gazi Üniversitesi, Ankara.

Aktürk, O.(2013). Imalat sanayiindeki KOBI'lerin sorunlarl ve 2008 küresel krizden etkilenme düzeyleri üzerine bir araştırma, Kırşehir ili örneği. Yayımlanmamış doktora tezi, Selçuk Üniversitesi, Konya.

Aypek, N. (2001). KOBİ finanslama sürecinde yeni finansman teknikleri. I. Avrasya küçük ve orta ölçekli işletmeler kongresi. Ankara:Tika Yayın Birimi.

Bozkurt, N. (2007). Küçük ve orta ölçekli işletmelerde yönetim sorunları. Yayımlanmamış yüksek lisans tezi, Niğde Üniversitesi, Niğde.

Coşkun, D. (2010). Finansal bilgi sisteminin işletme fonksiyonları üzerine etkisi: Aydın ili örneği, Yayımlanmamış yüksek lisans tezi, Süleyman Demirel Üniversitesi, Isparta.

Çelik, C. ve Karadal, H. (2007). KOBİlerin sorunları ve çözüm stratejilerinin algılanan performans üzerine etkileri: Aksaray ve Mersin örneği. Çukurova Üniversitesi, Sosyal Bilimler Enstitüsü Dergisi, (16/2), 119-138.

Çelik, İ. (2007).Basel II bağlamında KOBİlerin finansman sorunları: Tekstil sektöründe bir uygulama. Yayımlanmamış yüksek lisans tezi, Süleyman Demirel Üniversitesi, Isparta.

Güven, M. ve Yüksel, S. (2014). KOBİlerin yönetim ve organizasyon sorunlart: Trb-1 bölgesindeki işletmelerde bir araştırma. Yayınlanmamış yüksek lisans tezi, Bingöl Üniversitesi, Bingöl.

Kahraman,S.(2012).KOBİlerin sorunları ve çözüm önerileri; Bursa alan araştırması, Yayınlanmamış yüksek lisans tezi, Balıkesir Üniversitesi, Balıkesir.

Kulakoğlu, D. (2013). KOBİlerde yönetim ve organizasyon sorunlarının yaşanma düzeyi: Ankara KOBİ örneği. Yayınlanmamış yüksek lisans tezi, Gazi Üniversitesi, Ankara.

Müftüoğlu, M. T. (2002).Türkiye'de küçük ve orta ölçekli işletmeler KOBİler. Ankara: Turhan Kitabevi.

Özgener, Ş.(2003). Büyüme sürecindeki KOBİ'lerin yönetim ve organizasyon sorunlari: Nevşehir un sanayii örneği. Erciyes Üniversitesi İktisadi ve İdari Bilimler Fakültesi Dergisi, 20, 137-161. 
Özkanlı ve Namazalieva (2006).Kirgizistan'da faaliyet gösteren bazi küçük ve orta ölçekli işletmelerde yönetim sorunlari üzerine bir araştirma. Bilig Dergisi, 39, 97-125.

Öztürk, Ö. (2007). İstihdam konusunda KOBİlerin önemi ve KOBİ alanında eğitim istihdam ilişkisi açısından kamu istihdam kurumunun rolü. Ankara: Çalışma ve Sosyal Güvenlik Bakanlığı.

Resmi Gazete (2005). 12 Temmuz 2019 tarihinde www.resmigazete.gov.tr/2005/11/20051118.htm. adresinden erişildi.

Serinkan, C. ve Cabar, H.(2008). KOBİ'lerin yönetim ve organizasyon sorunları: Denizli' deki tekstil işletmelerinde bir araştırma. Uluslararası İnsan Bilimleri Dergisi, 5(1), 1-27.

Şimşek, M. (2002). Ekonominin lokomotifi KOBİlerin olmazsa olmazları. İstanbul: Alfa Yayınları.

Taş, Y. H. (2010). Avrupa Birliği ve Türkiye'de KOBI'lerin istihdam artırıcı etkileri. İstanbul: İTO.

Torlak, Ö. ve Uçkun, N.(2005).Eskişehir'deki KOBI'lerin pazarlama ve finansman sorunları ara kesiti. Sosyal Bilimler Dergisi, 1,199-215.

Tunca, M. Z. ve Yüce, G. (2007). Türkiye'de imalat yapan KOBI'lerin finansman sorunları ve çözüm önerleri: Samsun ilinde bir uygulama. Yayımlanmamış yüksek lisans tezi, Süleyman Demirel Üniversitesi, Isparta. 